IZA DP No. 9161

May There Be Victory:

Government Election Performance and the

World's Largest Public-Works Program

Laura Zimmermann

June 2015 


\title{
May There Be Victory: \\ Government Election Performance and the World's Largest Public-Works Program
}

\author{
Laura Zimmermann \\ University of Georgia \\ and IZA
}

Discussion Paper No. 9161

June 2015

IZA

P.O. Box 7240

53072 Bonn

Germany

Phone: +49-228-3894-0

Fax: +49-228-3894-180

E-mail: iza@iza.org

Any opinions expressed here are those of the author(s) and not those of IZA. Research published in this series may include views on policy, but the institute itself takes no institutional policy positions. The IZA research network is committed to the IZA Guiding Principles of Research Integrity.

The Institute for the Study of Labor (IZA) in Bonn is a local and virtual international research center and a place of communication between science, politics and business. IZA is an independent nonprofit organization supported by Deutsche Post Foundation. The center is associated with the University of Bonn and offers a stimulating research environment through its international network, workshops and conferences, data service, project support, research visits and doctoral program. IZA engages in (i) original and internationally competitive research in all fields of labor economics, (ii) development of policy concepts, and (iii) dissemination of research results and concepts to the interested public.

IZA Discussion Papers often represent preliminary work and are circulated to encourage discussion. Citation of such a paper should account for its provisional character. A revised version may be available directly from the author. 


\section{ABSTRACT \\ May There Be Victory: Government Election Performance and the World's Largest Public-Works Program*}

A number of developing country governments have introduced ambitious anti-poverty programs in recent years, but the dynamic effects of these initiatives on governments' election performance remain poorly understood. Especially in contexts with low program implementation quality, public support for government interventions may be high initially but decline over time as citizens observe the actual program benefits. This paper analyzes the election impacts of the largest public-works program in the world, the Indian NREGS. Using a regression-discontinuity framework, the results suggest that length of program exposure and implementation quality matter: voter support in low implementation quality areas declines with longer program access. This effect is muted in well-implemented areas, where voter turnout is higher and incumbents of any party affiliation also benefit. The government payoff from implementing a large anti-poverty program may therefore be short-lived unless implementation challenges are resolved.

JEL Classification: D72, H53, I38

Keywords: NREGS, election outcomes, India, anti-poverty programs, voting behavior

Corresponding author:

Laura Zimmermann

University of Georgia

Brooks Hall

310 Herty Drive

Athens, GA 30602

USA

E-mail: Ivzimmer@uga.edu

\footnotetext{
* I thank Manuela Angelucci, Raj Arunachalam, Jacob Shapiro, Jeffrey Smith, Rebecca Thornton, Dean Yang and participants at the CSAE Conference, the Annual Conference on Economic Growth and Development in Delhi, and the University of Michigan for valuable comments, feedback and suggestions. The paper was earlier circulated under the title 'Jai Ho? The Impact of a Large Public Works Program on the Government's Election Performance in India'.
} 


\section{Introduction}

Recent years have seen the introduction of a number of ambitious anti-poverty government programs in developing countries. These include conditional cash transfer programs meant to encourage school attendance or health checkups, as well as large public-works programs targeted at providing a safety net and more job opportunities. ${ }^{1}$ In terms of the broader effects of such initiatives, this development raises two questions: First, do citizens reward government parties for the introduction of such schemes in the short run? And second, what are the dynamic effects of voter approval in the face of widespread challenges in developing countries like implementation problems?

A growing literature analyzes the answer to the first question. A number of papers that focus predominantly on conditional cash transfer programs tends to find sizable pro-incumbent effects in the elections following the introduction of these programs by comparing treatment and control groups. ${ }^{2}$ This suggests that government programs at least initially provide important benefits for government parties and should function as an incentive to introduce such schemes. The findings are also consistent with the larger literature on governments' clientelist re-election strategies such as increased public spending in the year of the election or targeted programs that reach important sub-groups of society. In general, these strategies seem to be much more successful in developing countries than in the developed-country context. ${ }^{3}$

In contrast to this focus of the existing literature, hardly any paper explicitly analyzes the dynamic election effects of government initiatives. ${ }^{4}$ One notable exception is De la O (2013), who compares election effects for areas with longer and shorter exposure to the Mexican conditional cash transfer program Progresa, and finds that electoral support was higher among the early treatment

\footnotetext{
${ }^{1}$ See e.g. Subbarao et al. (2013) for an overview of public-works programs in developing countries.

${ }^{2}$ See e.g. the studies of conditional cash transfer programs in Brazil (Zucco 2010), Colombia (Baez et al. 2012, and Nupia 2011), Mexico (De la O 2013), the Philippines (Labonne 2013), and Uruguay (Manacorda et al. 2011). Pop-Eleches and Pop-Eleches (2012) analyze the impact of a voucher program in Romania.

${ }^{3}$ Despite the popularity of some of these strategies among governments around the world and the often held qualitative view that they help boost the incumbents' election performance, the evidence in developed countries is often mixed. In developing countries, on the other hand, most studies point to positive impacts. See e.g. Brender and Drazen (2005, 2008), Drazen and Eslava (2010), Finan and Schechter (2012).

${ }^{4}$ This may be at least partly due to the fact that many papers in the existing literature focus on Latin American conditional cash transfer programs that work very well empirically, so that dynamic effects may be less important (see e.g. Baez et al. 2012, De la O 2013, Manacorda et al. 2011).
} 
group. Especially in countries that face large-scale implementation problems with government programs, the overall medium- and long-run impact of an anti-poverty scheme on incumbent election outcomes is unclear a priori, however, since the effect at any given point in time is likely a combination of at least three effects: the election responses from citizens to awareness of the program, program salience in the vote choice for an election, and voters' updated expectations of program benefits based on implementation quality. Awareness is likely to be increasing in length of program exposure, salience of the program for citizens' vote choice may be decreasing, and the effect of better knowledge about implementation quality over time could be positive or negative depending on people's initial expectations. The medium and longer run implications of government programs for re-election could therefore be very different from the short-run benefits that are well documented in the literature. This is especially true if voters initially overestimate the program benefits by not adequately taking into account problems with implementation quality, which may be a realistic scenario in many developing countries. If voters hold the government accountable for poor delivery of benefits, vote benefits from such government initiatives may therefore decrease over time.

To the best of my knowledge, this paper is the first one to analyze the dynamic election impacts from an important government program in the face of large implementation problems. The paper analyzes the impact of the largest public-works program in the world, the Indian National Rural Employment Guarantee Scheme (NREGS), on national election outcomes. NREGS legally guarantees each rural household up to 100 days of manual public-sector work per year at the minimum wage and is supposed to be a completely demand-driven program where households can self-select into employment at any time during the year. A number of field studies and academic papers have highlighted sometimes very severe problems with implementation quality, although some benefits for the rural poor are still realized and there is substantial heterogeneity in the working of the program across India. Despite these shortcomings, the main government party played up the success of the scheme in its general election campaign, and the party itself as well as some experts and members of the popular press believe that NREGS was one of the main reasons for the surprising landslide victory of the government parties in $2009 .^{5}$

\footnotetext{
${ }^{5}$ See e.g. Khera (2010), Ramana (2009).
} 
The empirical analysis in this paper exploits variation in the timing of the introduction of NREGS across the country and the fact that the Indian government rolled out the program according to an algorithm which allows the use of a regression-discontinuity design. I find that votes for the government parties are lower in districts with a longer exposure to the employment guarantee scheme, with the impact being concentrated in states with low implementation quality. A high implementation quality increases voter turnout and balances this effect out, however, with the additional votes coming at the expense of the main national opposition party. Similar effects hold for constituency-level incumbents of any party affiliation.

The results are consistent with a story in which voters initially anticipate large benefits from the program but realize its practical limitations over time and become less enthusiastic about NREGS. This effect is muted in districts with higher implementation quality where satisfaction with the program is likely to be higher, and implies that voters hold both local-level politicians and national parties accountable for the performance of the employment guarantee. I provide evidence in the paper that the differential effects I find with a proxy for high implementation quality (whether a state has been classified as a 'star state' with respect to NREGS implementation or not) are consistent with a range of other results that suggest a more successful implementation of NREGS in these states.

Overall, the results suggest that the electoral benefits of implementing an ambitious antipoverty program may change substantially over time and that they may only last if the government resolves practical implementation issues. This is important for extending our understanding of the electoral impact of anti-poverty programs considered in the existing literature, which has focused on the short-run effect in areas with relatively high implementation quality. The findings support other existing evidence that better informed voters in developing countries increase the electoral accountability of governments and reduce malpractices (see e.g. Pande 2011). Banerjee et al. (2011), for example, find that voters in the slums of an Indian city who had randomly received information about the performance of the incumbent and two main other candidates had a higher voter turnout and were more likely to vote for more qualified candidates than those in control areas. 
Additionally, the nature of the Indian employment guarantee scheme also allows me to analyze which level in the federal state is held accountable for the program. This is an important consideration in many contexts where the central government pays for the program but where local authorities are responsible for implementing it, and especially where local-level politicians may have a different party affiliation than the government. The results from the Indian context here suggest that a well-implemented program benefits both the government parties and incumbents from any party, which implies that it is not necessarily in an opposition politician's interest to boycott the working of the program. This finding supports existing evidence in the literature that local politicians benefit from centrally funded programs (see e.g. Labonne 2013, Pop-Eleches and Pop-Eleches 2012). Lastly, the paper also extends our understanding of the impacts of the Indian employment guarantee scheme and how it may have impacted the peoples' relationship to the government. ${ }^{6}$

The rest of this paper is organized as follows: Section 2 provides some background information about the working of NREGS, the Indian electoral system, and the conceptual framework. Section 3 discusses the rollout of NREGS and the empirical estimation strategy. Section 4 presents the data sources and some summary statistics. Section 5 discusses the results. Section 6 concludes.

\section{Background}

\section{$2.1 \quad$ NREGS}

The National Rural Employment Guarantee Scheme (NREGS) is one of the largest and most ambitious government anti-poverty programs in the world. ${ }^{7}$ The scheme is based on the National

\footnotetext{
${ }^{6}$ While most existing papers on the program focus on the analysis of the economic benefits, the interpretation of the results in this paper is consistent with the explanation in Khanna and Zimmermann (2014) about the impact of NREGS on insurgency-related violence in India. Focusing on the short-run impacts in the early implementation phases, Khanna and Zimmermann (2014) find empirical patterns consistent with NREGS improving the relationship between civilians and government institutions like the police, which makes the police more efficient at tracking down insurgents. Both of these stories stress the anticipation effect of the program in the short run, whereas it may take time for people to experience the program themselves and to find out about the implementation problems.

${ }^{7}$ The program was renamed to Mahatma Gandhi National Rural Employment Guarantee Scheme in 2009. Since the abbreviations NREGA and NREGS are more established in the literature, however, I will keep referring to the program as NREGS. For more details on the scheme see e.g. Dey et al. (2006), Government of India (2009), Ministry of Rural Development (2010), and Zimmermann (2014).
} 
Rural Employment Guarantee Act (NREGA) which was passed in the Indian parliament in August 2005 and which provides a legal guarantee of up to 100 days of manual public-sector work per year at the minimum wage for each rural household. There are no other eligibility criteria, so households self-select into NREGS work and can apply for work at any time. Men and women are paid equally, and at any given time at least one third of the NREGS workforce is supposed to be female. Wages are the state minimum wage for agricultural laborers, although NREGA specifies national floor and ceiling values for the minimum wage. ${ }^{8}$ Wages need to be paid within 15 days of the day the work was performed, otherwise the worker is eligible for unemployment allowance. In practice, the focus of NREGS projects is on anti-drought measures and land development.

NREGS was rolled out across India in three phases: 200 districts received the program in February 2006 (Phase 1), 130 additional districts started implementing the scheme in April 2007 (Phase 2), and the remaining districts got NREGS in April 2008 (Phase 3). NREGS is now operating in 99 percent of Indian districts since it excludes districts with a 100 percent urban population (Ministry of Rural Development 2010).

NREGS has received widespread attention in the popular press and in academic research. The patterns emerging from a number of papers on the labor-market impacts of the employment guarantee suggest that while there are no large overall benefits of the scheme in terms of increased employment or higher private-sector casual wages, the program provides a safety net and works much better in some states than in others. Imbert and Papp (Forthcoming), Azam (2012) and Berg et al. (2012) use a difference-in-difference (DID) approach to look at the program's impact on wages and employment by exploiting the phase-in of the program over time. They find that NREGS seems to have led to higher public employment and increased private-sector wages in the agricultural off-season (Imbert and Papp Forthcoming), in areas with high implementation quality (Berg et al. 2012), and among casual workers (Azam 2012).

All of these papers need to rely on some version of the parallel trend assumption in their analyses, which is likely to be violated in practice because of the non-random roll-out of NREGS according to an economic underdevelopment ranking. Instead, Zimmermann (2014) reconstructs the

\footnotetext{
${ }^{8}$ The NREGS minimum wage was originally Rs.60, but has been raised various times since then. It was Rs.120 in 2009 .
} 
government algorithm used during the roll-out of the program and uses a regression-discontinuity framework to look at the overall labor-market impacts of the scheme. The empirical results suggest that NREGS is primarily used as a safety net rather than as an additional form of employment. The introduction of NREGS does not lead to an overall increase in public-sector employment or the casual private-sector wage. The program also does not create any additional jobs in the local economy and has no substantial impact on household expenditures or income. Consistent with the safety net function, however, take-up is higher after bad economic shocks, and workers seem to substitute away from private casual employment and towards other occupations like self-employment, which become relatively less risky with the introduction of a safety net. Johnson (2009a) also finds that NREGS provides a safety net for rural households in the Indian state of Andhra Pradesh since take-up of the program increases after negative rainfall shocks.

Due to the rapid phase-in of the employment guarantee scheme, most of these papers need to focus on the short-run impacts of NREGS, although the analysis in Berg et al. (2012) suggests that it may take some time for outcomes like higher casual private-sector wages to be realized. A growing literature points to large-scale problems with implementation quality, however: Dutta et al. (2012), for example, document widespread rationing of NREGS employment because of excess demand, and show that this is especially common in poorer states. Niehaus and Sukhtankar (2013a and 2013b) analyze the existence and characteristics of corruption in the implementation of NREGS in Orissa, and find that an increase in the minimum wage was not passed through to workers. NREGS seems to work much better in some other states like Andhra Pradesh, where Johnson (2009b) finds that the working of NREGS does not seem to be substantially affected by the specific party in power at the local panchayat level, suggesting that political pressures on NREGS in the state are not pervasive. This state heterogeneity is also routinely found in field reports of the working of the employment guarantee scheme on the ground, where the program seems to work relatively well in the so-called 'star states' (Andhra Pradesh, Chhattisgarh, Madhya Pradesh, Rajasthan, and Tamil Nadu), but faces severe challenges in the rest of the country (see e.g. Dreze and Khera 2009, Khera 2011).

Despite these implementation problems, NREGS has also been found to affect other outcomes in 
addition to the labor-market impacts. Klonner and Oldiges (2014) find some evidence of substantial reductions in poverty, and NREGS has also been credited with improving children's education outcomes (Afridi et al. 2012). Using the regression-discontinuity design, Khanna and Zimmermann (2014) find that insurgency-related violence in India increases in the short-run after NREGS is implemented. This pattern seems most consistent with the citizen-support channel, where citizens are willing to share more information about insurgents with the police after the introduction of the employment guarantee scheme because of actual or anticipated benefits of the program, which in turn makes the police more effective at tracking down rebels. This explanation implies that violence intensity should decline in the longer run as the ability of the insurgents to attack declines, which is consistent with results found in Fetzer (2013) and Dasgupta et al. (2014), although both papers attribute their results to a rise in the opportunity cost of being an insurgent after NREGS provides more employment opportunities.

Overall, the existing literature on the impacts of the employment guarantee scheme therefore suggests that the program has generated some economic benefits, and especially so in states with higher implementation quality, but that it may also have improved the relationship between civilians and the government more broadly. If this is true, NREGS may also have influenced the voting behavior of citizens in the next general elections.

\subsection{India's Political System and the General Elections of 2009}

India's electoral system works according to the first-past-the-post system, so the candidate with a plurality of the votes in a given constituency receives the seat in the Lok Sabha, the Indian parliament's lower house. Candidates can therefore be elected with much less than majority support, and the seat allocation can differ substantially from the allocation that would prevail under a proportional representation system. While the first-past-the-post system is often associated with few parliamentary parties, the last two decades have seen the rise of national coalition governments in India: The two big national parties, the Indian National Congress (INC) and the Bharatiya Janata Party (BJP), have created alliances with smaller parties to create working government coalitions called the United Progressive Alliance (UPA) and the National Democratic Alliance 
(NDA), respectively (see for example Yadav 1999). ${ }^{9}$ Even then governments do not always have a majority of seats in Parliament, however. The UPA government elected in 2004, for example, depended on external support from the Left Front (an alliance of left-wing parties) as well as that of two other parties. ${ }^{10}$

The membership of parties in the UPA and NDA has varied over the years. To the extent that small parties commit to a certain alliance before an election, parties often negotiate seat sharing agreements so that parties do not contest seats in all electoral constituencies and thus minimize vote-splitting between members of the same alliance. Additional negotiations can take place after elections and small parties have also left government coalitions or changed alliances.

The UPA won the general elections in 2004 and followed the previous NDA coalition government. The government coalition included the INC as the main national party as well as 13 smaller parties with mostly regional strongholds. ${ }^{11}$ The UPA membership before the 2009 general election differed from this composition after some parties left the coalition and new parties made agreements for the general elections, but since my research question focuses on the electoral benefits of a government program passed in parliament in 2005 I stick to the initial UPA composition for my empirical analysis.

For administrative and security reasons, the general elections of 2009 were held in five phases between April 16 and May 13. The election results were announced on May 16. Election dates are set, and elections monitored, by the autonomous Election Commission of India. ${ }^{12}$ Pre-polls had suggested a close race between UPA and NDA with a slight edge for the UPA, so the strong

\footnotetext{
${ }^{9}$ The 2014 national elections in India, which resulted in an absolute majority for the BJP, are an important deviation from this trend.

${ }^{10}$ The Left Front includes the Communist Party of India (Marxist), the Communist Party of India, the Revolutionary Socialist Party, and the All India Forward Bloc. The Bahujan Samaj Party and the Samajwadi Party.

${ }^{11}$ The small UPA member parties of the 2004 government are: Rashtriya Janata Dal, Dravida Munnetra Kazhagam, Nationalist Congress Party, Pattali Makkal Katchi, Telangana Rashtra Samithi, Jharkhand Mukti Morcha, Marumalarchi Dravida Munnetra Kazhagam, Lok Jan Shakti Party, Indian Union Muslim League, Jammu and Kashmir Peoples Democratic Party, Republican Party of India, All India Majlis-e-Ittehadul Muslimen, Kerala Congress (Times of India, 2006). Before the 2009 general elections, four parties left the government coalition: Telangana Rashtra Samithi, Marumalarchi Dravida Munnetra Kazhagam, Jammu and Kashmir Peoples Democratic Party, and Pattali Makkal Katchi. The empirical results are robust to excluding these parties from the UPA definition. Additional parties joined the UPA for 2009 elections, but I use the 2004 definition for my empirical analysis.

${ }^{12}$ The Election Commission had decided in 2006 that NREGS would not be allowed to be extended to more districts after the announcement of elections in any state, and that with very few exceptions employment would need to be provided in ongoing projects during that time. See http://www.righttofoodindia.org/data/ec2006nregacodeofconduct.jpg.
} 
performance of the UPA, and the INC in particular, came as a suprise for most experts (see for example Ramani 2009): The UPA won 262 of the 543 seats (2004: 218), with INC winning 206 seats, an increase of 61 seats relative to the 2004 election results. ${ }^{13}$ The NDA, on the other hand, lost support and only won 159 seats (2004: 181 seats). ${ }^{14}$ The Left Front also did much worse than predicted and won 79 seats.

The popular press as well as academic experts have advanced a number of hypotheses to explain the unexpectedly strong performance of the UPA, and INC in particular. These include the strong leadership skills of INC leaders Sonia and Rahul Gandhi, the competent and corruption-free image of prime minister Manmohan Singh, as well as intra-party problems in the BJP and regional factors (see for example EPW 2009, Ramani 2009). Many commentators believe, however, that one important factor for the UPA's election success was its focus on welfare policies and other government programs, and specifically NREGS (see e.g. Ramani 2009). INC's manifesto stressed NREGS as one of the main successes of the UPA government, and the party's slogan during the election campaign was Aam aadmi ke badhte kadam, har kadam par bharat buland (The common man moves forward, and with his every step India prospers). INC also bought the rights to the title song 'Jai Ho' (May there be victory) of the film Slumdog Millionaire, which tells the story of a boy from the slums who wins the Indian version of the quiz show 'Who Wants to Be a Millionaire?'. This focus on the poor is widely believed to have resonated with the electorate, and INC leaders have also claimed that the electoral victory was in large part due to NREGS. ${ }^{15}$ While such an election campaign strategy had been used repeatedly by INC in the past, experts stress that in contrast to previous campaigns which paid mere lip service to the party's commitment to the situation of the poor, the fact that NREGS was an actual ambitious government program made such claims credible. ${ }^{16}$

To test this hypothesis empirically, I exploit the phase-in of the employment guarantee scheme

\footnotetext{
${ }^{13}$ The absolute majority is 272 seats, so the UPA government is still reliant on external support. The UPA received 37.22 percent of the total vote (2004: 35.4 percent).

${ }^{14} 24.63$ percent of the votes (2004: 33.3 percent). NDA's biggest party and INC's main competitor, the BJP, won 116 seats (2004: 138 seats).

${ }^{15}$ See for example Khera (2010).

${ }^{16}$ Indira Gandhi's election campaign slogan for the general elections in 1971 was Garibi Hatao (Eradicate poverty), for example. See for example the comments on the election results by political science professors Thachil at casi.ssc.upenn.edu/iit/thachil and Kumbhar at www.mainstreamweekly.net/article1382.html.
} 
using a regression-discontinuity design.

\subsection{Conceptual Framework}

A number of existing papers document substantial election benefits for the government from implementing government programs in developing countries. The focus in most of these papers is on analyzing the mechanism driving these results and on understanding whether the mechanisms consistent with the results are a form of clientelistic policies, where governments strategically target segments of the population in exchange for votes, or an example of programmatic politics, where governments are rewarded for good performance (see e.g. De la O 2013, Manacorda et al. 2011, Pop-Eleches and Pop-Eleches 2012 for a more detailed discussion). The overall conclusion from the existing literature is, however, that it is beneficial for governments to use anti-poverty programs as a short-term strategy to improve their election performance.

A related question is whether the election benefits from government programs persist or even increase over time or whether they decrease. On the one hand, a longer program duration may mean a higher awareness of the program among the target population, a higher number of program beneficiaries, and a rise in implementation quality as government institutions learn how to implement the program more effectively. These effects would entail larger medium- and long-run benefits from government initiatives than those found in the short run, and are consistent with the finding in De la O (2013) that government election support was higher in the early Progresa treatment group than in the later treatment group.

On the other hand, a government program may lose its salience as an important factor in the vote choice of the people over time, especially when it is just one program among many. A longer exposure also gives citizens time to find out about implementation problems and to realize that the actual program benefits may not live up to their initial expectations. These effects should lower the electoral benefit from government programs over time.

The overall dynamic election effect of a government program is therefore a priori ambiguous and depends on the importance of at least three different components: the electoral effect of program awareness, which is likely to increase over time, of program salience, which may decrease, 
and of the updating of expectations of program benefits, whose trajectory depends on the initial expectations.

To analyze these dynamic effects, ideally we would want to observe how votes for the government in the same area change over time, which is typically impossible due to data constraints and potentially intervening other variables. In this paper, I focus on the next best case: the staggered rollout of the employment guarantee scheme in India over three phases according to an algorithm leads to quasi-experimental variation in the length of exposure of districts to the program at the time of the next general elections, and can be analyzed using a regression-discontinuity design at two cutoffs.

\section{$3 \quad$ NREGS Rollout and Empirical Strategy}

\subsection{NREGS Rollout}

NREGS was rolled out non-randomly in three phases between 2006 and 2008, with poor districts receiving the program earlier than more developed districts. Zimmermann (2014) reconstructs the algorithm that the Indian government used to assign districts to different implementation phases. The algorithm is intended to ensure inter-state and intra-state fairness norms and is therefore a two-step process: In the first step, a quota of treatment districts for each state in a given phase is determined, which is proportional to the prevalence of poverty across states. ${ }^{17}$ The "prevalence of poverty' measure is the state headcount ratio times the rural state population, which provides an estimate of the number of below-the-poverty-line people living in a given state. The headcount ratios are calculated from 1993-1994 National Sample Survey (NSS) data, whereas the rural state population numbers come from the 2001 Indian census. ${ }^{18}$

\footnotetext{
${ }^{17}$ In practice this provision also ensures that all states (union territories are usually excluded from such programs) receive at least one treatment district.

${ }^{18}$ The state headcount ratios used in this paper come from a Planning Commission document from 2009 since the original headcount ratio calculations do not have estimates for new states that had been created in the meantime (Planning Commission 2009). Since these are official Planning Commission estimates, they are likely to be closest to the information the Indian government would have had access to at the time of NREGS implementation. NSS is a nationally representative household survey dataset. The newest available information on headcount ratios at the time would have been the 1999-2000 NSS data, but that dataset was subject to data controversies and therefore not used.
} 
In the second step, the state-specific quotas are then filled by choosing a state's poorest districts according to a development ranking. The development index used to rank districts within states comes from a Planning Commission report from 2003 that created an index of 'backwardness', a term often used in India to refer to economic underdevelopment. The index was created from three outcomes for the 17 major states for which data was available: agricultural wages, agricultural productivity, and the proportion of low-caste individuals (Scheduled Castes and Scheduled Tribes) living in the district (Planning Commission 2003). Data on these outcomes was unavailable for the remaining Indian states, and it is unclear whether a comparable algorithm using different outcome variables was used for them. The empirical analysis is therefore restricted to these 17 states. Districts were ranked on their index values. In addition to using the economic development index for the algorithm, the government had a separate list of 32 districts with substantial Maoist violence. The 32 districts on this list were not subject to the economic development criterion and all received the employment guarantee scheme in the first phase of the roll-out. In order to closely replicate the used algorithm, these districts are dropped for the empirical analysis. ${ }^{19}$

The two-step algorithm results in state-specific cutoffs for treatment assignment for each implementation phase. Since there are three implementation phases, two cutoffs can be identified: the cutoff between Phase 1 and Phase 2, and the cutoff between Phase 2 and Phase 3. These cutoffs correspond to the Phase 1 and Phase 2 NREGS roll-out, respectively.

\subsection{Empirical Strategy}

The two cutoffs can be exploited empirically using a regression-discontinuity design. Since the general elections took place in 2009 when all rural districts had access to the program, the phasing in of the program provides variation in the length of time districts had been implementing the scheme. Since treatment cutoffs differ by state, ranks are made phase- and state-specific for the empirical analysis. To be able to pool observations from all states, the state-specific ranks are recentered such that a district with a normalized state-specific rank of zero is the last district in a state to be eligible for receiving the program in a given phase. All eligible districts have negative

\footnotetext{
${ }^{19}$ The results are qualitatively similar when the 32 districts are included in the analysis by assigning them the predicted rank based on their economic development index values.
} 
ranks, whereas the districts that should not receive NREGS in a given phase receive a postive normalized rank value. ${ }^{20}$

The overall prediction success rate of the assignment algorithm is 84 percent in Phase 1 and 82 percent in Phase 2. It is calculated as the percent of districts for which predicted and actual treatment status coincide. ${ }^{21}$ This means that there is some slippage in treatment assignment in both phases. Nevertheless, the algorithm performs quite well in almost all states and the prediction success rates are considerably higher than the expected rates from a random assignment of districts, which are 40.27 percent for Phase 1 and 37.45 percent for Phase 2 at the national level, respectively. Overall, this suggests that the proposed algorithm works well for predicting Phase 1 and Phase 2 district allocations.

As there is some slippage in district assignment, the empirical identification strategy is a fuzzy RD design. The fundamental assumption of the empirical strategy is that districts that were just poor enough to receive the program in a given phase of the NREGS rollout, and districts that were just too developed to be included in a given phase are similar to each other. Then, discontinuities in the outcome variables for these two types of districts can be solely attributed to the differences in the duration of having had access to NREGS.

One important component of this assumption is that beneficiaries need to have been unable to perfectly manipulate their treatment status (Lee 2008). Otherwise, districts close to the cutoff on either side are not plausibly similar to each other in terms of unobservables such as the perceived program benefit. In the case of the two-step RD, this means that districts should not have been able to manipulate their predicted status under the algorithm in either step.

This seems plausible: As mentioned above, the headcount poverty ratio used to calculate the number of treatment districts for a state in the first step of the algorithm used data from the mid-1990s, which had long been available by the time the NREGS assignment was made. ${ }^{22}$ Sim- $^{-}$ ilarly, the 'backwardness' index used in the second step was constructed from outcome variables

\footnotetext{
${ }^{20}$ This section follows the information in Zimmermann (2014) closely.

${ }^{21}$ Prediction success rates for Phase 2 are calculated after dropping Phase 1 districts from the analysis.

${ }^{22}$ The algorithm also uses state rural population numbers from the 2001 Census to transform headcount ratios into absolute numbers, but those figures were also long publicly available at the time. The RD may be potentially fuzzier than it really is because of some potential for measurement error introduced into the algorithm at this step since the exact numbers the government used in this step are not known
} 
collected in the early to mid-1990s, eliminating the opportunity for districts to strategically misreport information. Additionally, the suggestion of the original Planning Commission report had been to target the 150 least developed districts, but the NREGS cutoff of 200 districts in Phase 1 was already higher than this. ${ }^{23}$ Lastly, the Planning Commission report lists the raw data as well as the exact method by which the development index was created, again eliminating room for districts to manipulate their rank. Overall, it therefore seems like manipulation of the rank variable is not a major concern. ${ }^{24}$

Figures $1 \mathrm{a}$ and $1 \mathrm{~b}$ focus more closely on the distribution of index values over state-specific ranks. Ideally, the assignment variable should be continuous at the cutoff, since discontinuities at the cutoffs are typically taken as signs of manipulation. The figures plot the relationship between the Planning Commission's index and the normalized state-specific ranks for the Phase 1 and Phase 2 cutoffs, respectively. For most states, the poverty index values seem smooth at the cutoff of zero, again suggesting that manipulation of the underlying poverty index variable is not a big concern.

Another way of analyzing whether manipulation is likely to be a problem is to test whether there are any discontinuities at the cutoffs in the baseline data, although this is only a relatively crude test in this case since the boundaries of the electoral constituencies were re-drawn before the 2009 general election so that there is no perfect correspondence between the 2009 election outcomes and the baseline election outcomes from 2004. Nevertheless, we should not find impacts in the baseline data if the only factor that is driving any outcome differences in 2009 is the introduction of NREGS. Appendix Tables A.8, A.9, and A.10 present the results of such an analysis for the main outcome variables used in this paper (the vote share and winning constituency variables for INC, UPA, the left front and the BJP, the voter turnout, and the incumbent won and vote share variables) for three different parametric specifications for the 2004 general elections for both cutoffs. They show that only three of 66 coefficients are statistically significant and that those are not robust

\footnotetext{
${ }^{23}$ Therefore, districts would have had an incentive to be among the 150 poorest districts but not to be among the 200 or 330 least developed districts for Phase 1 and Phase 2, respectively.

${ }^{24}$ This does not mean that actual treatment assignment was not subject to political pressures since compliance with the algorithm is often below 100 percent. It can be shown that deviations from the algorithm are correlated with party affiliation. This is also consistent with Gupta (2006) who analyzes the relationship between rule deviations and party affiliation for an earlier program. That paper ignores the fact that the program most likely also used the two-step algorithm, however, which could substantially affect the results.
} 
across different parametric specifications. Overall, this test suggests again that manipulation is unlikely to be an important problem. Zimmermann (2014) and Khanna and Zimmermann (2014) also document that districts are also similar at baseline with respect to a number of other labor market and Maoist violence variables.

With a fuzzy RD design, we also need to verify that there is indeed a discontinuity in the probability of receiving the program at the state-specific cutoff values for NREGS districts. Figures 1c and 1d show this graphically for the normalized state-specific cutoffs for Phase 1 and Phase 2, respectively. They plot the probability of receiving NREGS in the given phase for each bin, as well as fitted quadratic regression curves and corresponding 95 percent confidence intervals on either side of the cutoff. The graphs show that the average probability of receiving NREGS jumps down by about 40 percentage points at both discontinuities.

\section{Data, Variable Creation and Empirical Specification}

\subsection{Data and Variable Creation}

The election outcome data used in this paper are the official general election results of 2009 from the Election Commission of India. ${ }^{25}$ For each electoral constituency, the Election Commission lists all candidates, their party affiliation, and the number of votes received per candidate as well as some limited candidate background information like gender, age, and broad caste category. It also gives the number of eligible voters in a given constituency, which allows the calculation of voter turnout.

Election constituencies are created to ensure fair votes-to-seat ratios that are roughly equal across the country, and therefore do not correspond perfectly to other administrative boundaries in India. Since NREGS was rolled out at the district level, I match each election constituency to the closest appropriate district. The matching is done according to the name of the election constituency, which is usually a major city. ${ }^{26}$ To this dataset, I merge information on the poverty

\footnotetext{
${ }^{25}$ Data are publicly available at http://eci.nic.in. The Election Commission of India is an autonomous body that schedules and oversees elections.

${ }^{26}$ All electoral constituencies used in the empirical analysis can be matched non-ambiguously to one district. I use district boundaries from the 2001 Census to make these matches. The procedure of using the constituency
} 
index rank from the 2003 Planning Commission Report, district population size from the 2001 Census as well as information on a district's NREGS phase and some NREGS implementation quality information from the official government NREGS website. ${ }^{27}$ This NREGS implementation quality information includes the number of individuals and households employed under NREGS in a given district, the number of households reaching the limit of 100 days, and the total persondays generated by NREGS. All these variables are for the financial year 2008-09, which is roughly the year before the general elections take place and the only time span in which districts from all phases had access to NREGS. ${ }^{28}$ At the time of the general elections in April 2009, Phase 1 districts had had NREGS for three years, Phase 2 districts for two years, and Phase 3 districts for one year. As an alternative measure of the implementation quality of NREGS I also create an indicator variable equal to 1 if a constituency belongs to what has been called a 'star state', and 0 otherwise. Field reports on the working of NREGS in Dreze and Khera (2009) and Khera (2011) identify five states in which NREGS seems to be implemented better than in the rest of the country: Andhra Pradesh, Chhattisgarh, Madhya Pradesh, Rajasthan, and Tamil Nadu.

I create various outcome variables to measure the impact NREGS had on the general election results. Since India has a first-past-the-post system, an important outcome is the number of constituencies in which a party received the plurality of the vote since this directly translates to seats won in the Lok Sabha. I therefore create index variables equal to 1 if a given party or alliance won a plurality of votes in a constituency, and 0 otherwise. I also create variables of the received vote share of parties and alliances in a constituency. The empirical analysis focuses on the UPA government coalition and its main party the INC as well as the INC's main national competitor, the BJP, and the Left Front. I also look at voter turnout. In addition to these national level outcome variables, I also look at the election outcomes of incumbents. An incumbent here is an individual who won the 2004 general election in any electoral constituency in India and contested the elections again in 2009.

name introduces some measurement error since election constituencies can span parts of more than one district, but this is uncommon. Furthermore, assigning such a constituency to the district that the constituency name's town is drawn from minimizes this measurement error since more local election results are not available. In most cases, there is one electoral constituency per district.

${ }^{27}$ The NREGS website is http://nrega.nic.in.

${ }^{28}$ The financial year starts on April 1. 


\subsection{Empirical Specification}

India had 543 electoral constituencies in the 2009 general elections, but corresponding district Planning Commission rank information needed for the implementation of the regression discontinuity design is only available for 406 of them. ${ }^{29}$ As the number of observations near the cutoffs is therefore limited, I use parametric regressions to estimate the impact of NREGS empirically. To test the robustness of the estimates, all main result tables show the estimated coefficients for linear and quadratic regression curves in the running variable with and without constraining the slope of the curves to be the same on both sides of the cutoffs. ${ }^{30}$

I estimate the treatment effect at the discontinuity separately for the two cutoffs. For each cutoff the running variable is the state-specific rank variable for the corresponding implementation phase. I drop the 32 insurgency-affected districts that received NREGS in the first phase, since these received the program regardless of their poverty level. The middle category of Phase 2 districts is taken as the reference group, so that the coefficients for Phase 1 and Phase 3 directly provide the estimated treatment effect at the two cutoffs. It is important to note that since the RD design depends on observations being close to the cutoff for identification it is impossible to compare Phase 1 and Phase 3 districts directly, since these will be far apart from each other by design.

The equation below shows the regression equation for one of the specifications I run, which is linear in the running variable but does not constrain the coefficients to be the same on either side of the cutoff:

$$
y_{i j}=\beta_{0}+\beta_{1} \operatorname{rank}_{i}+\beta_{2} \text { nregs }_{i}+\beta_{3} \text { nregs } * \operatorname{rank}_{i}+\epsilon_{i j}
$$

where the subscripts refer to constituency $i$ in district $j . y$ is an outcome variable of interest, whereas nregs is an indicator variable equal to 1 if a district is predicted to receive NREGS in that phase according to the algorithm, and zero otherwise. rank is a district's rank based on the state-

\footnotetext{
${ }^{29}$ Rank information is intentionally missing for urban districts, since the employment program is targeted to rural areas, as well as for some small states, especially in the North-East, where the data required for the district rank had not been collected in the 1990s. Otherwise, the data is complete for all districts within the covered states.

${ }^{30}$ Using F-tests I cannot reject the null hypothesis that other higher-order polynomial terms are irrelevant. The quadratic flexible specification is always statistically outperformed by the linear flexible specification. Furthermore, Gelman and Imbens (2014) discourage the use of higher-order polynomials.
} 
specific normalized index. The coefficient of interest is $\beta_{2}$. Since we are dealing with a fuzzy RD rather than a sharp RD, this specification is the intent-to-treat (ITT) specification. Standard errors are clustered at the district level. The main results in the paper report the estimates from using a donut hole approach. One concern with the regression discontinuity design in this paper is that measurement error in the running variable may lead to the misclassification of some observations close to the cutoff. The donut-hole specifications drop districts with normalized state-specific ranks of $-1,0$, and 1 to see whether this issue is a major concern for the estimates. The RD graphs show the results for the full sample, however, as do the corresponding tables in the appendix, which are similar to the main results.

The validity of the RD design does not depend on the availability of baseline information, although including such variables as controls can improve the precision of the estimates. Since the electoral constituency boundaries were redrawn between the 2004 and 2009 general elections, and boundaries changed for 499 of the 543 constituencies, it is unclear whether the 2004 outcomes provide good control variables for the 2009 election results. Therefore, my main results do not include control variables.

\subsection{Summary Statistics}

Table 1 presents some summary statistics for the sample used for the empirical analysis separately by NREGS phase. As we can see, voter turnout in the 2009 general elections was about 60 percent in Phase 1 and Phase 2 constituencies, although a bit lower in Phase 3 constituencies. The probability of winning a seat is between 33 and 38 percent for INC and weakly increasing in the phase number. This pattern is more pronounced for all the parties belonging to the UPA taken together, where the probability of receiving a plurality of the vote is about 39 percent in Phase 1 constituencies, but about 48 percent in Phase 3 districts. By contrast, the pattern for the INC's main national competitor, the BJP, follows a U-shape, whereas the probability of winning decreases for the Left Front in later NREGS phases. The winning probability of the BJP is around 20 percent, whereas the Left Front's chances are much lower. The corresponding average vote shares for the parties and the UPA reveal that a higher average vote share is not necessarily 
associated with a higher probability of winning a seat.

The last two rows provide an overview of the implementation quality of NREGS, giving the number of persons employed under the scheme in the financial year 2008-09 as well as the corresponding number of generated person-days. These data come from administrative sources, since nationally representative information from other sources for the same time span is unavailable. Research by Niehaus and Sukhtankar (2013a and 2013b) has shown that at least in the state of Orissa administrative data vastly overstates actual employment because of corruption, although it less clear how big this problem is nationwide. This means that employment statistics in Table 1 should be interpreted cautiously. They do suggest, however, that employment generation in Phase 3 districts in their first year of implementing the program is lagging significantly behind the areas that have had access to NREGS for a longer period.

\section{Results}

\subsection{Main Results}

Tables 2 to 7 analyze the impact of NREGS on the 2009 general election outcomes for the national parties as well as the local-level incumbents using a donut hole approach. ${ }^{31}$

Tables 2 and 3 present the overall impact of the employment guarantee scheme for the UPA coalition government and its main party, the INC, as well as for the two main competitor parties, the BJP and the Left Front. The outcome variables include indicator variables equal to 1 if a given party or coalition won in an electoral constituency, vote share variables that give the achieved share of the vote in a constituency in percent, and the voter turnout. The reference category in both tables are electoral constituencies in Phase 2 NREGS districts, and the results are reported for three different parametric specifications.

As can be seen from these results, the overall impact of the length of exposure to the employment guarantee scheme is relatively limited, although a number of coefficients are economically significant

\footnotetext{
${ }^{31}$ The donut-hole approach drops observations with normalized state-specific rank values of 0 and 1 due to concerns with measurement error right around the cutoff. Corresponding tables for the results for the full sample are reported in the appendix.
} 
but imprecisely estimated. In Table 2, the estimated coefficients for the INC and UPA outcome variables are typically large and negative, although usually statistically insignificant, implying for example a reduction in the probability that the INC wins in electoral constituencies by about 18 percentage points in the first row for Phase 1 districts relative to Phase 2 districts. The Left Front parties, on the other hand, do consistently better in Phase 1 districts at the cutoff with an about 6 percentage point higher probability of winning a plurality of the votes. This effect is statistically significant at the 10 percent level. The results for the vote share outcome variables follow a similar pattern and the estimated coefficients typically have the same sign as their corresponding 'won' outcome variables but are imprecisely estimated.

A similar pattern emerges in Table 3 for Phase 3 districts relative to Phase 2 districts at the cutoff. Again, districts with a longer exposure to NREGS (2 years versus 1 year) tend to vote less for the government parties, with two out of three coefficients being statistically significant at the 5 percent level for the government coalition UPA's vote share, although the other coefficients are again imprecisely estimated. There is also some evidence for voter turnout being lower in Phase 3 districts than in Phase 2 districts.

Tables 4 and 5 reveal that the overall results mask important heterogeneity with respect to implementation quality, however. The main NREGS variable here is interacted with an indicator variable equal to 1 if the district is part of a so-called 'star state' where the employment guarantee scheme is relatively well implemented according to field studies by NGOs and social activists. ${ }^{32}$ Table 4 shows that there is a large negative impact of NREGS on the winning probability for the government parties in Phase 1 non-star districts that is always statistically significant at at least the 10 percent level. This negative effect of longer exposure to the employment guarantee scheme is substantially reduced in Phase 1 star states. The reverse pattern is apparent for the main competitor of the government parties, the BJP, where votes in Phase 1 star-state districts are statistically significantly lower than those in non-star Phase 1 districts. Additionally, voter turnout is also statistically significantly higher in star states on the order of 12 percentage points.

These results suggest that citizens in Phase 1 districts, i.e. districts that have had access to

\footnotetext{
${ }^{32}$ Awareness of the program and implementation quality tend to be much higher in star states than in the rest of the country (Dreze and Khera 2009, Khera 2011).
} 
NREGS for three years at the time of the elections, are less willing to reward the government parties for the anti-poverty program than citizens in Phase 2 districts unless the program works well. Additional votes for the government in Phase 1 star-state districts cut into the votes for the BJP, but also lead to a higher voter turnout than in non-star states.

The mirror image of this pattern emerges when comparing Phase 3 to Phase 2 districts in Table 5, which again implies that voters in districts with longer exposure to NREGS may overall be less willing to vote for the government parties than districts that received NREGS in Phase 3 (although the main effects are here typically imprecisely estimated), but that a high implementation quality in star-states reverses this effect. As in Table 4, star-state districts with longer exposure (Phase 2 districts) see an increase in voter turnout and lower votes for the BJP than non-star Phase 2 districts.

People in districts that had just received the program in the year prior to the elections therefore seem to be the ones most willing to vote for the government, whereas individuals in districts with longer access to the scheme care much more about implementation quality. These patterns are consistent with the idea that people initially may have high expectations of NREGS, leading them to support the government. The more time they have to experience the program themselves or hear about the implementation problems associated with it, however, the less positive they may feel about NREGS and the government.

Tables 6 and 7 extend the analysis for the national parties to the impacts for incumbents. An incumbent is defined as an individual who won a plurality of votes in an electoral constituency in the 2004 general elections and competed again in the 2009 general election in any electoral constituency. Table 6 shows that incumbents of any party affiliation are not statistically significantly more likely to win again in Phase 1 districts relative to Phase 2 districts or in Phase 3 relative to Phase 2 districts.

Table 7 reveals that implementation quality is again an important source of heterogeneity when comparing Phase 2 and Phase 3 districts, with star-state districts with longer exposure to NREGS being more likely to re-elect incumbents than non-star districts. This is similar to the corresponding impacts for the national parties in Tables 4 and 5, and again suggests that voters become more 
sensitive to implementation quality with longer exposure to the employment guarantee scheme. With the central government paying for most of the costs of NREGS, but with the local level being responsible for implementing the program, it makes sense that we find similar patterns for incumbents and national parties.

Figures $2 \mathrm{a}$ through $2 \mathrm{~h}$ show the main results graphically for star states and non-star states. Overall, the empirical results suggest that voters hold both the national government parties and the local-level incumbents responsible for the implementation of the employment guarantee scheme. While voters in the last implementation group (Phase 3) seem to be the most positive about NREGS, the people with long exposure to the program, who have presumably had time to experience the program themselves or hear about from others, are less likely to reward the responsible parties unless implementation quality is high.

\subsection{Robustness Checks and Extensions}

The robustness of the empirical results is tested in a number of robustness checks reported in the appendix. Tables A.11 to A.16 analyze the impact of NREGS on the 2009 general election outcomes for the national parties as well as the local-level incumbents without using the donut-hole approach, and show that the results are similar for the full sample. Tables A.17 to A.19 present the results using a probit specification instead of a linear probability model for the constituency won outcome variables. Tables A.20 to A.25 re-estimate the main results using a treated-onthe-treated (TOT) specification where actual receipt of NREGS is instrumented with predicted NREGS receipt according to the algorithm. Lastly, Table A.26 shows that the star-state results are also present when using a difference-in-difference approach to estimate the impact of NREGS on election outcomes.

Another potential concern with interpreting the main results is that the star-state heterogeneity may not actually reflect differences in implementation quality, but could be driven by other factors. To test whether there are indeed differences in implementation quality of NREGS between star states and other states Tables A.27 to A.29 use available information on the allocation of finances and labor-market outcomes at the district level. Table A.27 uses administrative information on the 
allocation of financial resources under NREGS in 2008/2009 on four dimensions: centrally released funds, total available funds, total expenditures, and administrative expenditures. The results show that star-state districts with longer exposure to NREGS do not spend statistically significantly more money than other districts of the same implementation phase and are not allocated more money, although the interaction effects are positive and often economically significant. But starstates have statistically significantly higher administrative costs, which is consistent with the idea that star-state administrations implement the employment guarantee scheme more thoroughly.

Tables A.28 and A.29 use available data on worker outcomes from administrative data and from National Sample Survey household survey data from 2009/2010. Column 1 in both tables reveals that according to administrative data early star-state districts employ fewer people than other districts from the same implementation phase, which could be due to a lower number of ghost workers and less corruption in star states that lead to over-reporting of generated employment in other areas. The household-survey data in the remaining columns shows that individuals in star-state districts have higher wages and per-capita consumption. The interaction effect for public employment is also positive for longer-exposed star-state districts, although the coefficients are imprecisely estimated. Overall, Tables A.27 to A.29 are therefore consistent with the idea that star states really have a higher implementation quality of NREGS than districts in other states, although I cannot completely rule out that there are other differences unrelated to NREGS implementation quality between star states and other states that drive these differential effects.

\section{Conclusion}

This paper has analyzed the impact of a major government anti-poverty program in India, the National Rural Employment Guarantee Scheme (NREGS), on the government's performance in the next general elections. Using a regression discontinuity framework, I find that approval for the government parties seems to decline with the length of exposure to the program, with the effect concentrated in districts with low implementation quality. A high implementation quality, on the other hand, balances out this effect and is associated with a higher voter turnout. Votes for the government come at the expense of the main national opposition party, although incumbents of any 
party affiliation benefit from NREGS in well-implemented areas. The results are consistent with a story in which it takes some time for voters to learn about the implementation quality of NREGS, but where voters realize the practical limitations of the program after having had the scheme for some time and become less enthusiastic about NREGS in areas with substantial implementation challenges.

Overall, the results show that there is an electoral benefit of implementing ambitious antipoverty programs in India. At the same time, however, the empirical analysis suggests that such electoral payoffs may be relatively short-lived if the government is not really committed to a highquality implementation of such programs. While election campaigns can serve to inform people about existing government policies and remind them of the benfits of the schemes, such a strategy may not be successful with voters in the longer run. Many voters seem to care about the actual benefits government initiatives like NREGS provide, and not just about a verbal commitment to the fight against poverty. This points to the rise of 'programmatic politics' where patronage networks alone are no longer sufficient to win elections and would therefore imply a deepening of democracy. ${ }^{33}$

Whlie it is difficult to disentangle different theories of why citizens are more likely to vote for incumbents in areas where the government program works relatively well, the results are consistent with voters viewing the implementation of NREGS as a signal of competence and a commitment to the fight against poverty, which promise more benefits after the election (see e.g. Drazen and Eslava 2010). This seems to be a view implicitly held by a number of commentators on the election success of the Indian government who stressed the fact that NREGS marked the first time that a government had actually implemented a very ambitious anti-poverty program and not mostly relied on lip service of the importance of economic development. The empirical results can also be explained with a model of reciprocity, however, where voters simply reward the government for its past performance (see e.g. Finan and Schechter 2012).

\footnotetext{
${ }^{33}$ See e.g. De la O (2013) for a similar conclusion for the election impacts of Progresa in Mexico.
} 


\section{References}

Afridi, Farzana, Abhiroop Mukhopadhyay, and Soham Sahoo. 2012. 'Female Labour Force Participation and Child Education in India: The Effect of the National Rural Employment Guarantee Scheme' IZA Discussion Paper 6593.

Azam, Mehtabul. 2012. 'The Impact of Indian Job Guarantee Scheme on Labor Market Outcomes: Evidence from a Natural Experiment.' IZA Discussion Paper 6548.

Baez, Javier, Adriana Camacho, Emily Conover, and Romn Zrate. Conditional Cash Transfers, Political Participation, and Voting Behavior. IZA Discussion Paper No. 6870, September 2012.

Banerjee, Abhijit, Selvan Kumar, Rohini Pande, and Felix Su. 2011. 'Do Informed Voters Make Better Choices? Experimental Evidence from Urban India.' Mimeo.

Berg, Erlend, Sambit Bhattacharyya, Rajasekhar Durgam, and Manjula Ramachandra. 2012. 'Can Rural Public Works Affect Agricultural Wages? Evidence from India.' CSAE Working Paper WPS/2012-05.

Brender, A., and A. Drazen. 2005. 'Political Budget Cycles in New versus Established Democracies.' Journal of Monetary Economics, 52: 1271-1295.

Brender, A., and A. Drazen. 2008. 'How Do Budget Deficits and Economic Growth Affect Reelection Prospects? Evidence from a Large Panel of Countries' American Economic Review, 98 : 2203-2220.

Calonico, Sebastian, Cattaneo, Matias, and Rocio Titiunik. Forthcoming. 'Optimal Data-Driven Regression Discontinuity Plots.' Journal of the American Statistical Association.

Dasgupta, Adi, Kishore Gawande, and Devesh Kapur. 2014. 'Can Anti-poverty Programs Reduce Conflict? India's Rural Employment Guarantee and Maoist Insurgency,' Mimeo.

De la O, Ana. 2013. 'Do Conditional Cash Transfers Affect Electoral Behavior? Evidence from a Randomized Experiment in Mexico.' American Journal of Political Science, 57(1): 1-14.

Dey, Nikhil, Jean Dreze, and Reetika Khera. 2006. Employment Guarantee Act: A Primer. (Delhi: National Book Trust, India)

Drazen, Allen and Marcela Eslava. 2010. 'Electoral Manipulation via Voter-Friendly Spending: Theory and Evidence.' Journal of Development Economics, 92: 39-52.

Dreze, Jean and Reetika Khera. 2009. 'The Battle for Employment Guarantee.' Frontline, 26(1). Dutta, Puja, Rinku Murgai, Martin Ravallion, and Dominique van de Walle. 2012. 'Does India's Employment Guarantee Scheme Guarantee Enployment?' World Bank Policy Research Working Paper 6003.

Economic and Political Weekly (EPW). 2009. 'Defeated But Still a Threat.' Economic and Political Weekly, XLIV(24): 6.

Fetzer, Thiemo. 2013. 'Can Workfare Programs Moderate Violence? Evidence from India,' Mimeo. 
Finan, Frederico and Laura Schechter. 2012. 'Vote-Buying and Reciprocity.' Econometrica, 80(2): 863-881.

Gelman, Andrew and Guido Imbens. 2014. 'Why High-order Polynomials Should not be used in Regression Discontinuity Designs' NBER Working Paper 20405

Government of India. 2009. 'The National Rural Employment Guarantee Act.'

Gupta, Santanu. 2006. 'Were District Choices for NFFWP Appropriate?' Journal of the Indian School of Political Economy, 18(4): 641-648.

Imbert, Clement, and John Papp. Forthcoming. 'Labor Market Effects of Social Programs: Evidence of India's Employment Guarantee.' American Economic Journal: Applied Economics.

Johnson, Doug. 2009a. 'Can Workfare Serve as a Substitute for Weather Insurance? The Case of NREGA in Andhra Pradesh.' Institute for Financial Management and Research, Centre for Micro Finance, Working Paper 32.

Johnson, Doug. 2009b. 'How Do Caste, Gender and Party Affiliation of Locally Elected Leaders Affect Implementation of NREGA?' Institute for Financial Management and Research, Centre for Micro Finance Working Paper 33.

Khanna, Gaurav and Laura Zimmermann. 2014. Guns and Butter? Fighting Violence with the Promise of Development. Mimeo.

Khera, Reetika. 2010. 'Wages of Delay.' Frontline, 27(10).

Khera, Reetika. 2011. The Battle for Employment Guarantee. Oxford University Press.

Klonner, Stefan and Christian Oldiges. 2014. 'Employment Guarantee and Its Welfare Effects in India.' Mimeo.

Labonne, Julien. 2013. 'The Local Electoral Impacts of Conditional Cash Transfers : Evidence from a Field Experiment.' Journal of Development Economics, 104: 73-88.

Lee, David S. 2008. 'Randomized Experiments from Non-Random Selection in U.S. House Elections.' Journal of Econometrics, 142(2): 675-697.

Lee, David S., and Thomas Lemieux. 2010. 'Regression Discontinuity Designs in Economics.' Journal of Economic Literature, 48(2): 281-355.

Manacorda, Marco, Edward Miguel, and Andrea Vigorito. 2011. 'Government Transfers and Political Support.' American Economic Journal: Applied Economics, 3(3).

Ministry of Rural Development, Department of Rural Development, Government of India. 2010. 'Mahatma Gandhi National Rural Employment Guarantee Act 2005 - Report to the People 2nd Feb 2006 - 2nd Feb 2010.'

Niehaus, Paul, and Sandip Sukhtankar. 2013a. 'The Marginal Rate of Corruption in Public Programs.' Journal of Public Economics, 104: 52-64.

Niehaus, Paul, and Sandip Sukhtankar. 2013b. 'Corruption Dynamics: The Golden Goose Effect.' American Economic Journal: Economic Policy, 5(4): 230-269. 
Nupia, O. 2011. 'Anti-Poverty Programs and Presidential Election Outcomes: Familias En Accion in Colombia.' Working Paper, Universidad de los Andes.

Pande, Rohini. 2011. 'Can Informed Voters Enforce Better Governance? Experiments in Low Income Democracies.' Annual Review of Economics, 3(1): 215-237.

Planning Commission. 2003. 'Report of the Task Force: Identification of Districts for Wage and Self Employment Programmes.'

Planning Commission. 2009. 'Report of the Expert Group to Review the Methodology for Estimation of Poverty.'

Pop-Eleches, Cristian and Grigore. 2012. 'Government Spending and Pocketbook Voting: QuasiExperimental Evidence from Romania.' Quarterly Journal of Political Science, 7(30).

Ramani, Srinivasan. 2009. 'A Decisive Mandate.' Economic and Political Weekly, XLIV(21): 1112.

Subbarao, K., del Ninno, C., Andrews, C., C. and Rodrguez-Alas. 2013. Public Works as a Safety Net - Design, Evidence and Implementation. Washington DC: World Bank.

Times of India. 2006. 'United Progressive Alliance: Partners in Governance.' July 8.

Yadav, Yogendra. 1999. 'Electoral Politics in the Time of Change.' Economic and Political Weekly, 34(34/35): 2393-2399.

Zimmermann, Laura. 2014. 'Why Guarantee Employment? Evidence from a Large Indian PublicWorks Program.' Mimeo.

Zucco, Cesar. 2010. 'Cash Transfers and Voting Behavior: An Assessment of the Political Impacts of the Bolsa Familia Program.' Mimeo. 
Table 1: Summary Statistics

\begin{tabular}{lccc} 
& Phase 1 & Phase 2 & Phase 3 \\
\hline $\mathrm{N}$ & 170 & 106 & 225 \\
voter turnout & 0.6003 & 0.6087 & 0.5796 \\
INC win & 0.3353 & 0.3585 & 0.3778 \\
UPA win & 0.3882 & 0.4151 & 0.4800 \\
BJP win & 0.2176 & 0.1792 & 0.2356 \\
Left Front win & 0.0294 & 0.0189 & 0.0044 \\
INC vote share & 26.36 & 24.83 & 29.36 \\
UPA vote share & 35.95 & 32.15 & 37.54 \\
BJP vote share & 17.25 & 17.63 & 21.96 \\
Left Front share & 2.84 & 1.96 & 1.23 \\
NREGS employment & 114563 & 120385 & 58419 \\
NREGS person days & 2182372 & 2224858 & 1674907 \\
\hline
\end{tabular}

Note: Vote shares given in percent. INC (Indian National Congress), UPA (United Progressive Alliance), BJP (Bharatiya Janata Party) UPA is the name of the government coalition. For the government elected in 2004, the UPA consisted of the following parties: Indian National Congress, Rashtriya Janata Dal, Dravida Munnetra Kazhagam, Nationalist Congress Party, Pattali Makkal Katchi, Telangana Rashtra Samithi, Jharkhand Mukti Morcha, Marumalarchi Dravida Munnetra Kazhagam, Lok Jan Shakti Party, Indian Union Muslim League, Jammu and Kashmir Peoples Democratic Party, Republican Party of India, All India Majlis-e-Ittehadul Muslimen, Kerala Congress. The Left Front is an alliance of left-wing parties and includes the Communist Party of India (Marxist), the Communist Party of India, the Revolutionary Socialist Party, and the All India Forward Bloc. 
Table 2: Election Results Phase 1 vs Phase 2

\begin{tabular}{|c|c|c|c|c|c|c|c|c|c|c|}
\hline & \multicolumn{4}{|c|}{ won constituencies } & \multicolumn{4}{|c|}{ vote share in percent } & \multirow[b]{2}{*}{$\begin{array}{c}\text { voter turnout } \\
\qquad(9)\end{array}$} \\
\hline & & $\begin{array}{l}\text { INC } \\
(1)\end{array}$ & $\begin{array}{c}\text { UPA } \\
(2)\end{array}$ & $\begin{array}{c}\text { Left } \\
(3)\end{array}$ & $\begin{array}{l}\text { BJP } \\
(4)\end{array}$ & $\begin{array}{l}\text { INC } \\
(5)\end{array}$ & $\begin{array}{c}\text { UPA } \\
(6)\end{array}$ & $\begin{array}{c}\text { Left } \\
(7)\end{array}$ & $\begin{array}{c}\text { BJP } \\
(8)\end{array}$ & \\
\hline & $\begin{array}{c}\text { NREGS Phase } 1 \\
\text { (Linear) }\end{array}$ & $\begin{array}{l}-0.1830^{*} \\
(0.0953)\end{array}$ & $\begin{array}{c}-0.2057^{* *} \\
(0.0976)\end{array}$ & $\begin{array}{l}0.0552^{*} \\
(0.0301)\end{array}$ & $\begin{array}{l}-0.0616 \\
(0.0740)\end{array}$ & $\begin{array}{l}-7.90^{*} \\
(4.06)\end{array}$ & $\begin{array}{c}-9.29 * * \\
(4.26)\end{array}$ & $\begin{array}{c}0.64 \\
(1.95)\end{array}$ & $\begin{array}{l}-2.38 \\
(3.56)\end{array}$ & $\begin{array}{l}-0.0343 \\
(0.0330)\end{array}$ \\
\hline \multirow[t]{3}{*}{ ¿ } & $\begin{array}{c}\text { NREGS Phase } 1 \\
\text { (Linear flexible) }\end{array}$ & $\begin{array}{l}-0.0915 \\
(0.1019)\end{array}$ & $\begin{array}{l}-0.1118 \\
(0.1044)\end{array}$ & $\begin{array}{l}0.0657^{*} \\
(0.0394) \\
\end{array}$ & $\begin{array}{l}-0.0741 \\
(0.0761)\end{array}$ & $\begin{array}{l}-3.91 \\
(4.35) \\
\end{array}$ & $\begin{array}{l}-6.14 \\
(4.69) \\
\end{array}$ & $\begin{array}{l}1.76 \\
(2.24) \\
\end{array}$ & $\begin{array}{l}-3.44 \\
(3.67) \\
\end{array}$ & $\begin{array}{c}0.0288 \\
(0.0319) \\
\end{array}$ \\
\hline & $\begin{array}{c}\text { NREGS Phase } 1 \\
\text { (Quadratic) }\end{array}$ & $\begin{array}{l}-0.0672 \\
(0.1071)\end{array}$ & $\begin{array}{l}-0.0646 \\
(0.1096)\end{array}$ & $\begin{array}{l}0.0710^{*} \\
(0.0402)\end{array}$ & $\begin{array}{l}-0.0707 \\
(0.0788)\end{array}$ & $\begin{array}{l}-2.35 \\
(4.59)\end{array}$ & $\begin{array}{l}-3.45 \\
(4.95)\end{array}$ & $\begin{array}{l}1.79 \\
(2.36)\end{array}$ & $\begin{array}{l}-2.71 \\
(3.82)\end{array}$ & $\begin{array}{c}0.0358 \\
(0.0352)\end{array}$ \\
\hline & $\mathrm{N}$ & 354 & 354 & 354 & 354 & 354 & 354 & 354 & 354 & 354 \\
\hline
\end{tabular}

Note: ${ }^{* * *} \mathrm{p}<0.01,{ }^{* *} \mathrm{p}<0.05,{ }^{*} \mathrm{p}<0.1$ Standard errors clustered at the district level in parentheses. An observation is an election constituency in the 2009 general election. Parametric regressions with different levels of flexibility are reported. Vote shares are given in percent. The won variables are indicator variables equal to 1 if a given party received a plurality of the votes in a constituency, and 0 otherwise. The results use a donut-hole approach. 
Table 3: Election Results Phase 2 vs Phase 3

\begin{tabular}{|c|c|c|c|c|c|c|c|c|c|}
\hline & & won cons & ituencies & & & te share & n perc & & \\
\hline & $\begin{array}{l}\text { INC } \\
(1)\end{array}$ & $\begin{array}{c}\text { UPA } \\
(2)\end{array}$ & $\begin{array}{c}\text { Left } \\
(3)\end{array}$ & $\begin{array}{l}\text { BJP } \\
(4)\end{array}$ & $\begin{array}{c}\text { INC } \\
(5)\end{array}$ & $\begin{array}{c}\mathrm{UPA} \\
(6)\end{array}$ & $\begin{array}{l}\text { Left } \\
(7)\end{array}$ & $\begin{array}{c}\text { BJP } \\
(8)\end{array}$ & $\begin{array}{c}\text { voter turnout } \\
\qquad(9)\end{array}$ \\
\hline $\begin{array}{c}\text { NREGS Phase } 3 \\
\text { (Linear) }\end{array}$ & $\begin{array}{l}-0.0893 \\
(0.0903)\end{array}$ & $\begin{array}{l}-0.0487 \\
(0.0934)\end{array}$ & $\begin{array}{l}-0.0166 \\
(0.0189)\end{array}$ & $\begin{array}{c}0.0375 \\
(0.0761)\end{array}$ & $\begin{array}{l}-1.52 \\
(3.73)\end{array}$ & $\begin{array}{c}4.07 \\
(3.61)\end{array}$ & $\begin{array}{l}-1.50 \\
(1.38)\end{array}$ & $\begin{array}{c}0.24 \\
(3.51)\end{array}$ & $\begin{array}{c}-0.1106^{* * *} \\
(0.0282)\end{array}$ \\
\hline $\begin{array}{c}\text { NREGS Phase } 3 \\
\text { (Linear flexible) }\end{array}$ & $\begin{array}{l}-0.0126 \\
(0.0996)\end{array}$ & $\begin{array}{c}0.0476 \\
(0.1044)\end{array}$ & $\begin{array}{l}-0.0146 \\
(0.0190)\end{array}$ & $\begin{array}{c}0.0199 \\
(0.0892)\end{array}$ & $\begin{array}{c}1.87 \\
(4.09)\end{array}$ & $\begin{array}{l}8.55^{* *} \\
(3.69) \\
\end{array}$ & $\begin{array}{l}-0.64 \\
(1.47)\end{array}$ & $\begin{array}{l}-1.63 \\
(3.91)\end{array}$ & $\begin{array}{l}-0.0483^{*} \\
(0.0274)\end{array}$ \\
\hline $\begin{array}{c}\text { NREGS Phase } 3 \\
\text { (Quadratic) }\end{array}$ & $\begin{array}{c}0.0209 \\
(0.1084)\end{array}$ & $\begin{array}{c}0.0924 \\
(0.1131)\end{array}$ & $\begin{array}{r}0.0034 \\
(0.0187) \\
\end{array}$ & $\begin{array}{l}-0.0184 \\
(0.0991)\end{array}$ & $\begin{array}{c}1.80 \\
(4.43) \\
\end{array}$ & $\begin{array}{l}9.72^{* *} \\
(4.01)\end{array}$ & $\begin{array}{l}0.25 \\
(1.53) \\
\end{array}$ & $\begin{array}{l}-4.41 \\
(4.27)\end{array}$ & $\begin{array}{l}-0.0227 \\
(0.0295)\end{array}$ \\
\hline $\mathrm{N}$ & 375 & 375 & 375 & 375 & 375 & 375 & 375 & 375 & 375 \\
\hline
\end{tabular}

Note: ${ }^{* * *} \mathrm{p}<0.01,{ }^{* *} \mathrm{p}<0.05,{ }^{*} \mathrm{p}<0.1$ Standard errors clustered at the district level in parentheses. An observation is an election constituency in the 2009 general election. Parametric regressions with different levels of flexibility are reported. Vote shares are given in percent. The won variables are indicator variables equal to 1 if a given party received a plurality of the votes in a constituency, and 0 otherwise. The results use a donut-hole approach. 
Table 4: State Results Phase 1 vs Phase 2

\begin{tabular}{|c|c|c|c|c|c|c|c|c|c|}
\hline & & won const & uencies & & & ote share & n perce & & \\
\hline & $\begin{array}{c}\mathrm{INC} \\
(1)\end{array}$ & $\begin{array}{l}\text { UPA } \\
(2)\end{array}$ & $\begin{array}{c}\text { Left } \\
(3)\end{array}$ & $\begin{array}{l}\text { BJP } \\
(4)\end{array}$ & $\begin{array}{c}\text { INC } \\
(5)\end{array}$ & $\begin{array}{c}\text { UPA } \\
(6)\end{array}$ & $\begin{array}{l}\text { Left } \\
(7)\end{array}$ & $\begin{array}{c}\text { BJP } \\
(8)\end{array}$ & $\begin{array}{c}\text { voter turnout } \\
\qquad(9)\end{array}$ \\
\hline $\begin{array}{c}\text { NREGS Phase } 1 \\
\text { (Linear) }\end{array}$ & $\begin{array}{c}-0.2783^{* * *} \\
(0.1022)\end{array}$ & $\begin{array}{c}-0.3065^{* * *} \\
(0.1036)\end{array}$ & $\begin{array}{l}0.0769^{*} \\
(0.0399)\end{array}$ & $\begin{array}{l}-0.0022 \\
(0.0845)\end{array}$ & $\begin{array}{c}-10.09^{* *} \\
(4.53)\end{array}$ & $\begin{array}{c}-11.71^{* *} \\
(4.60)\end{array}$ & $\begin{array}{c}0.18 \\
(2.38)\end{array}$ & $\begin{array}{c}1.84 \\
(3.79)\end{array}$ & $\begin{array}{c}-0.0846^{* *} \\
(0.0377)\end{array}$ \\
\hline NREGS Phase $1^{*}$ star & $\begin{array}{l}0.2451^{*} \\
(0.1265) \\
\end{array}$ & $\begin{array}{c}0.2330^{* *} \\
(0.1162) \\
\end{array}$ & $\begin{array}{c}-0.0604^{* *} \\
(0.0306) \\
\end{array}$ & $\begin{array}{r}-0.1811^{*} \\
(0.0954) \\
\end{array}$ & $\begin{array}{c}4.72 \\
(4.82) \\
\end{array}$ & $\begin{array}{c}4.11 \\
(4.71) \\
\end{array}$ & $\begin{array}{l}1.75 \\
(2.19) \\
\end{array}$ & $\begin{array}{c}-13.47^{* * *} \\
(4.86)\end{array}$ & $\begin{array}{c}0.1467^{* * *} \\
(0.0380)\end{array}$ \\
\hline $\begin{array}{l}\text { NREGS Phase } 1 \\
\text { (Linear flexible) }\end{array}$ & $\begin{array}{l}-0.1941^{*} \\
(0.1102)\end{array}$ & $\begin{array}{c}-0.2299 * * \\
(0.1118)\end{array}$ & $\begin{array}{l}0.0974^{*} \\
(0.0539)\end{array}$ & $\begin{array}{l}-0.0058 \\
(0.0877)\end{array}$ & $\begin{array}{l}-5.99 \\
(5.06)\end{array}$ & $\begin{array}{l}-9.20^{*} \\
(5.30)\end{array}$ & $\begin{array}{l}1.67 \\
(2.88)\end{array}$ & $\begin{array}{c}1.17 \\
(3.99)\end{array}$ & $\begin{array}{l}-0.0150 \\
(0.0383)\end{array}$ \\
\hline NREGS Phase $1 *$ star & $\begin{array}{l}0.1981^{*} \\
(0.1284)\end{array}$ & $\begin{array}{l}0.1902^{*} \\
(0.1192) \\
\end{array}$ & $\begin{array}{r}-0.0719 * \\
(0.0376) \\
\end{array}$ & $\begin{array}{r}-0.1791^{*} \\
(0.0948)\end{array}$ & $\begin{array}{c}2.43 \\
(4.99) \\
\end{array}$ & $\begin{array}{c}2.70 \\
(5.01) \\
\end{array}$ & $\begin{array}{c}0.91 \\
(2.41) \\
\end{array}$ & $\begin{array}{c}-13.10^{* * *} \\
(4.92) \\
\end{array}$ & $\begin{array}{c}0.1078^{* * *} \\
(0.0375)\end{array}$ \\
\hline $\begin{array}{c}\text { NREGS Phase } 1 \\
\text { (Quadratic) }\end{array}$ & $\begin{array}{l}-0.1844 \\
(0.1153)\end{array}$ & $\begin{array}{l}-0.1994^{*} \\
(0.1169)\end{array}$ & $\begin{array}{l}0.1044^{*} \\
(0.0546)\end{array}$ & $\begin{array}{l}-0.0001 \\
(0.0905)\end{array}$ & $\begin{array}{l}-4.95 \\
(5.29)\end{array}$ & $\begin{array}{l}-7.00 \\
(5.58)\end{array}$ & $\begin{array}{c}1.67 \\
(2.99)\end{array}$ & $\begin{array}{c}2.05 \\
(4.18)\end{array}$ & $\begin{array}{l}-0.0144 \\
(0.0418)\end{array}$ \\
\hline NREGS Phase $1 *$ star & $\begin{array}{l}0.2108^{*} \\
(0.1281)\end{array}$ & $\begin{array}{l}0.1938^{*} \\
(0.1180)\end{array}$ & $\begin{array}{c}-0.0705^{* *} \\
(0.0353)\end{array}$ & $\begin{array}{r}-0.1818^{*} \\
(0.0949)\end{array}$ & $\begin{array}{c}2.84 \\
(4.99)\end{array}$ & $\begin{array}{c}2.39 \\
(4.96)\end{array}$ & $\begin{array}{c}1.20 \\
(2.35)\end{array}$ & $\begin{array}{c}-13.55^{* * *} \\
(4.91)\end{array}$ & $\begin{array}{c}0.1210^{* * *} \\
(0.0378)\end{array}$ \\
\hline $\mathrm{N}$ & 354 & 354 & 354 & 354 & 354 & 354 & 354 & 354 & 354 \\
\hline
\end{tabular}

Note: ${ }^{* * *} \mathrm{p}<0.01,{ }^{* *} \mathrm{p}<0.05,{ }^{*} \mathrm{p}<0.1$ Standard errors clustered at the district level in parentheses. An observation is an election constituency in the 2009 general election. Parametric regressions with different levels of flexibility are reported. Vote shares are given in percent. The won variables are indicator variables equal to 1 if a given party received a plurality of the votes in a constituency, and 0 otherwise. Star state is an indicator variable equal to 1 if a state was identified as a high implementation quality state, and 0 otherwise. The five star states are Andhra Pradesh, Chhattisgarh, Madhya Pradesh, Rajasthan and Tamil Nadu. The results use a donut-hole approach. 
Table 5: Star State Results Phase 2 vs Phase 3

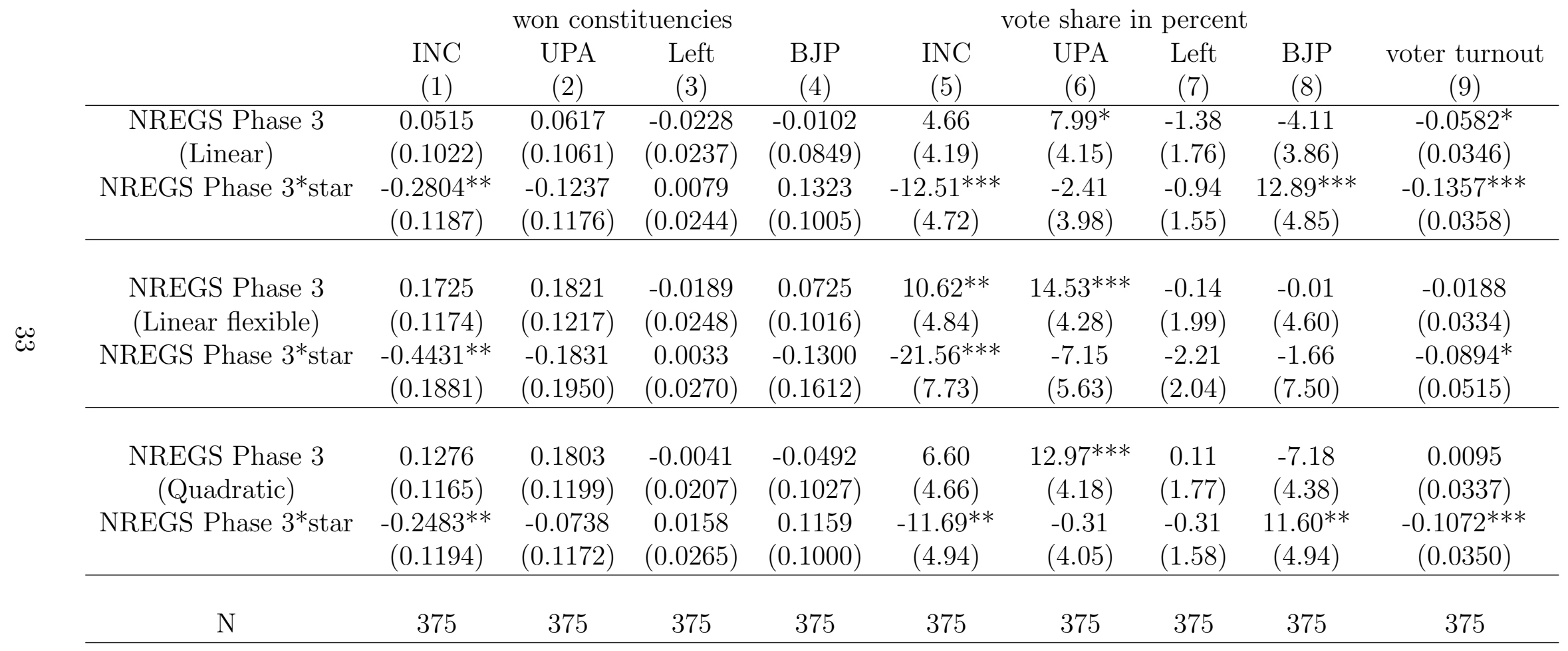

Note: $* * * \mathrm{p}<0.01, * * \mathrm{p}<0.05, * \mathrm{p}<0.1$ Standard errors clustered at the district level in parentheses. An observation is an election constituency in the 2009 general election. Parametric regressions with different levels of flexibility are reported. Vote shares are given in percent. The won variables are indicator variables equal to 1 if a given party received a plurality of the votes in a constituency, and 0 otherwise. The results use a donut-hole approach. 


\section{Table 6: Incumbent Results}

incumbent Phase 1 vs 2 incumbent Phase 2 vs 3

\begin{tabular}{ccccc} 
& won & vote share & won & vote share \\
& $(1)$ & $(2)$ & $(3)$ & $(4)$ \\
\hline NREGS & 0.1184 & 1.34 & 0.0256 & -1.42 \\
(Linear) & $(0.0833)$ & $(3.49)$ & $(0.0821)$ & $(3.71)$ \\
\hline NREGS & 0.1361 & 2.51 & 0.0504 & 0.18 \\
(Linear flexible) & $(0.0900)$ & $(3.81)$ & $(0.0913)$ & $(4.05)$ \\
\hline NREGS & $0.1588^{*}$ & 3.12 & 0.0594 & -0.76 \\
(Quadratic) & $(0.0928)$ & $(4.02)$ & $(0.1014)$ & $(4.40)$ \\
\hline $\mathrm{N}$ & 354 & 354 & 375 & 375 \\
\hline
\end{tabular}

Note: ${ }^{* * *} \mathrm{p}<0.01,{ }^{* *} \mathrm{p}<0.05,{ }^{*} \mathrm{p}<0.1$ Standard errors clustered at the district level in parentheses. An observation is an election constituency in the 2009 general election. Parametric regressions with different levels of flexibility are reported. Vote shares are given in percent. The won variables are indicator variables equal to 1 if a given party received a plurality of the votes in a constituency, and 0 otherwise. An incumbent is an individual who won a plurality of votes in his/her constituency in the 2004 general elections and who contested the 2009 elections in any constituency. The results use a donut-hole approach. 
Table 7: Incumbent Star Results

incumbent Phase 1 vs 2 incumbent Phase 2 vs 3

\begin{tabular}{ccccc} 
& won & vote share & won & vote share \\
& $(1)$ & $(2)$ & $(3)$ & $(4)$ \\
\hline NREGS & 0.0557 & 0.28 & $0.1761^{*}$ & 2.12 \\
(Linear) & $(0.0895)$ & $(3.85)$ & $(0.0938)$ & $(4.15)$ \\
NREGS*star & 0.1888 & 3.24 & $-0.4036^{* * *}$ & $-9.67^{* *}$ \\
& $(0.1247)$ & $(4.99)$ & $(0.1083)$ & $(4.77)$ \\
\hline NREGS & 0.0533 & 0.80 & 0.1791 & 5.79 \\
(Linear flexible) & $(0.0987)$ & $(4.38)$ & $(0.1103)$ & $(4.63)$ \\
NREGS*star & 0.3220 & 11.82 & $-0.4227^{* *}$ & $-17.47^{* *}$ \\
& $(0.2711)$ & $(9.91)$ & $(0.1739)$ & $(8.09)$ \\
\hline NREGS & 0.0898 & 2.20 & 0.1712 & 1.86 \\
(Quadratic) & $(0.1011)$ & $(4.49)$ & $(0.1088)$ & $(4.67)$ \\
NREGS*star & 0.1764 & 2.53 & $-0.4057^{* * *}$ & $-9.78^{* *}$ \\
& $(0.1266)$ & $(5.02)$ & $(0.1099)$ & $(4.87)$ \\
\hline N & 354 & 354 & 375 & 375 \\
\hline
\end{tabular}

Note: ${ }^{* * *} \mathrm{p}<0.01,{ }^{* *} \mathrm{p}<0.05,^{*} \mathrm{p}<0.1$ Standard errors clustered at the district level in parentheses. An observation is an election constituency in the 2009 general election. Parametric regressions with different levels of flexibility are reported. Vote shares are given in percent. The won variables are indicator variables equal to 1 if a given party received a plurality of the votes in a constituency, and 0 otherwise. The results use a donut-hole approach. 
Figure 1: Distribution of Index and Discontinuities by Phase

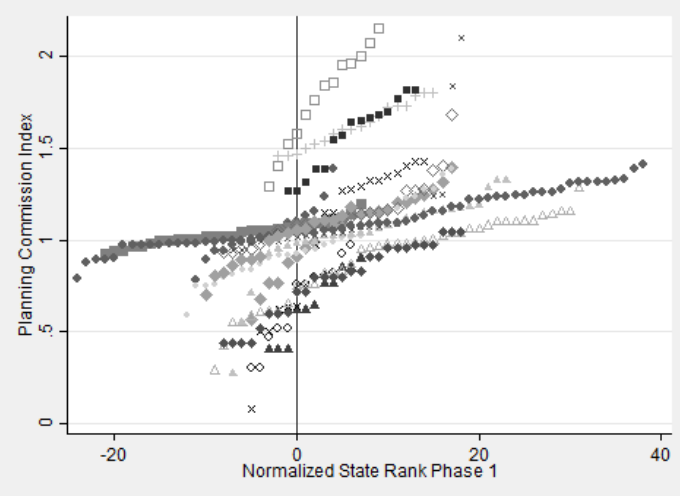

(a) Distribution of Index - Phase 1

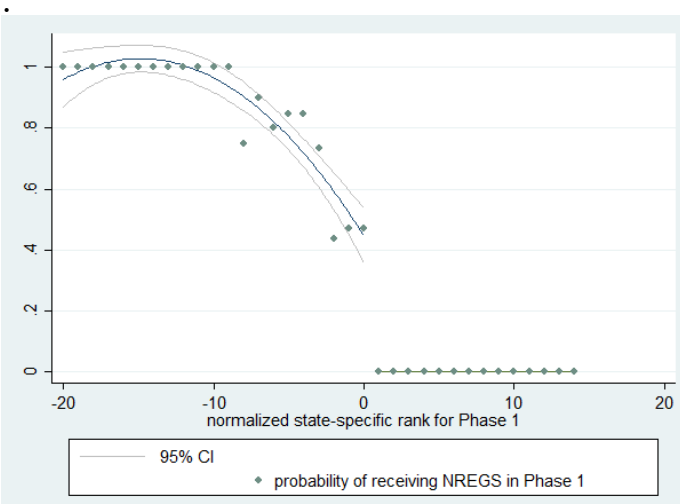

(c) Phase 1 Discontinuity

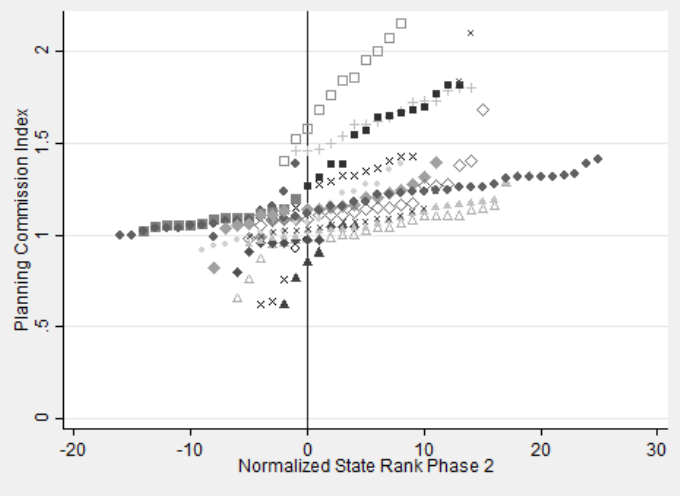

(b) Distribution of Index - Phase 2

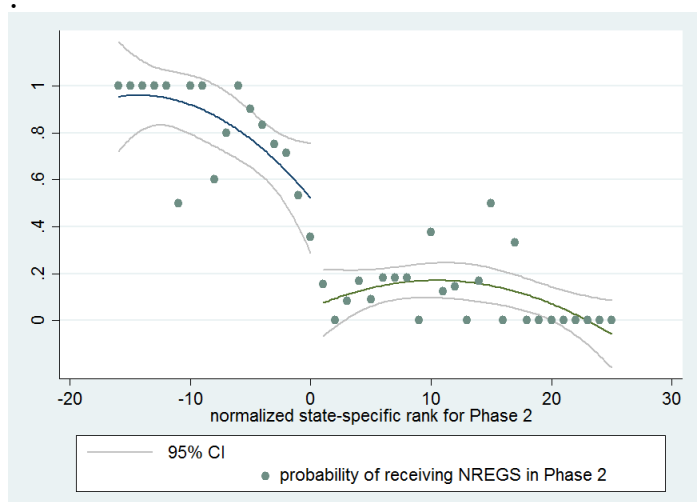

(d) Phase 2 Discontinuity

Note: First row plots the distribution of the index by state. Second row shows the treatment discontinuities for each phase, dropping the phase far away from the cutoff (Phase 3 in (c), Phase 1 in (d)). Negative and zero normalized state rank numbers are districts that should have received NREGS based on the government algorithm, whereas positive numbers are assigned to districts that should have been ineligible. 
Figure 2: Discontinuities for Main Variables

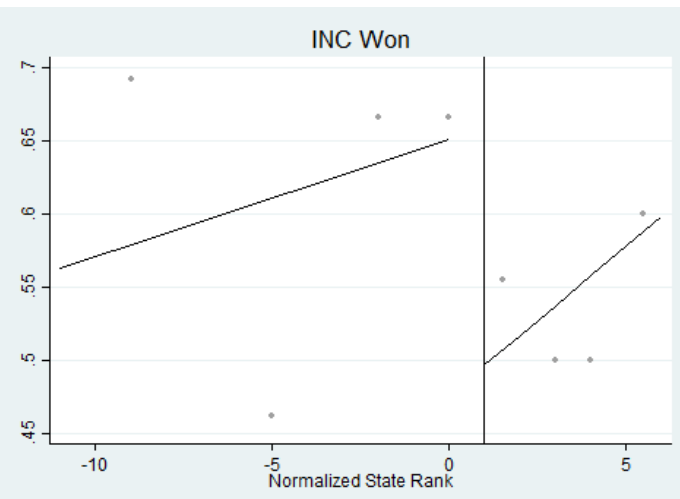

(a) INC Won Star-State Phase 1

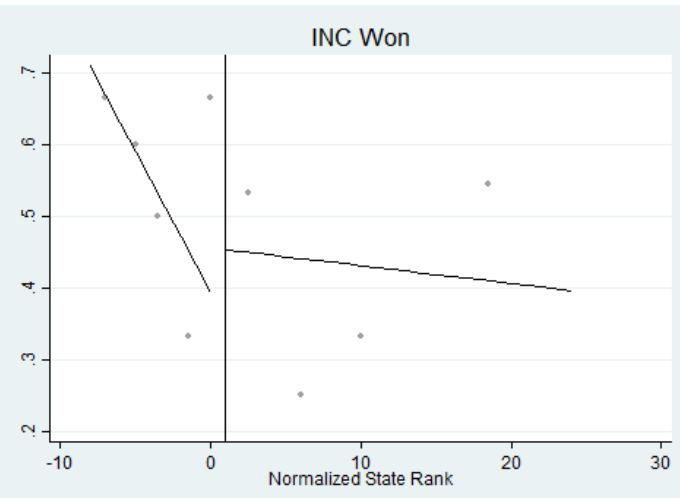

(c) INC Won Star-State Phase 2

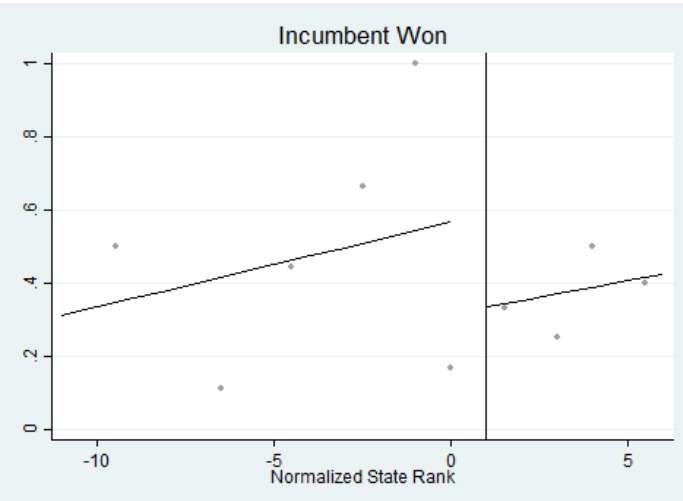

(e) Incumbent Won Star-State Phase 1

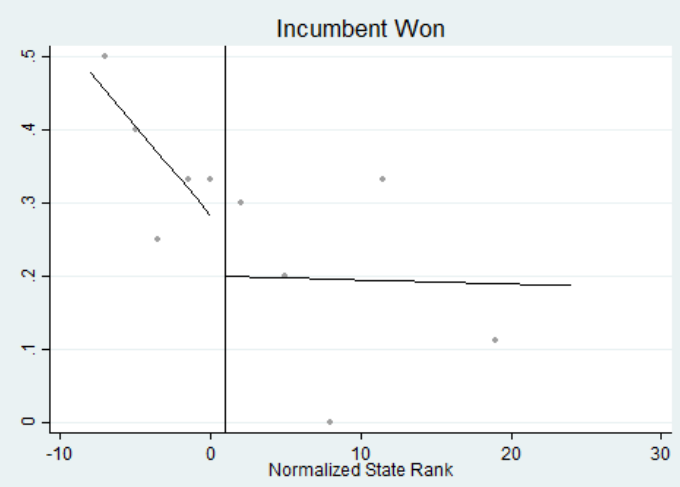

(g) Incumbent Won Star-State Phase $23 \frac{\text { h }}{2}$ ) Incumbent Won Non-Star-State Phase

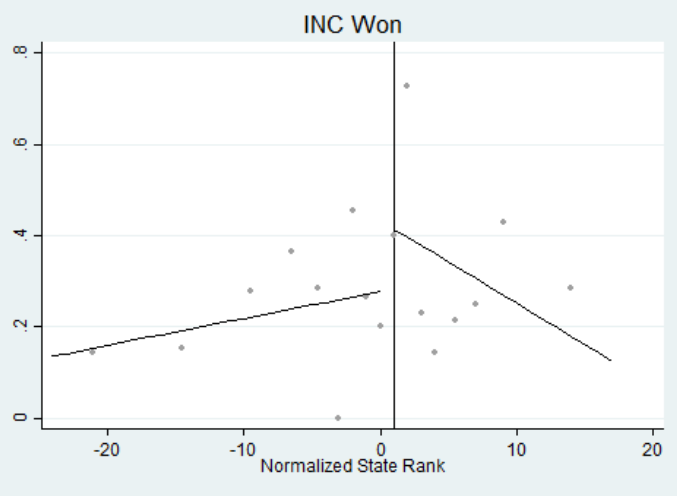

(b) INC Won Non-Star-State Phase 1

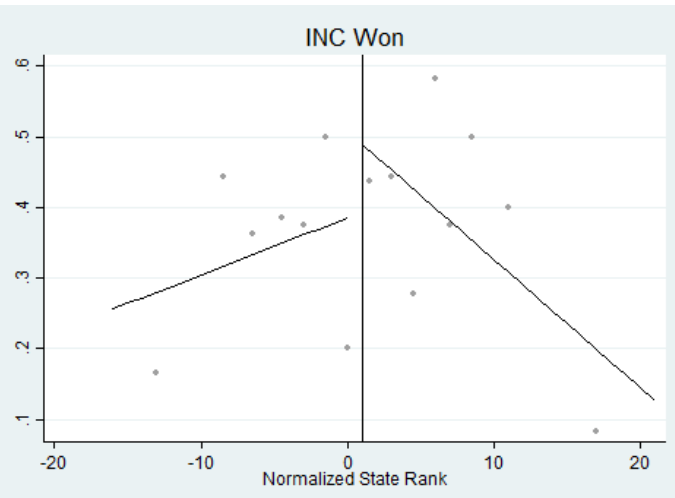

(d) INC Won Non-Star-State Phase 2

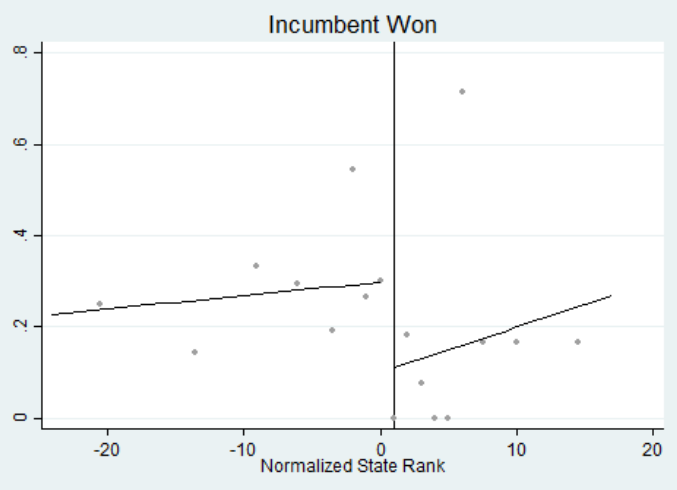

(f) Incumbent Won Non-Star-State Phase 1

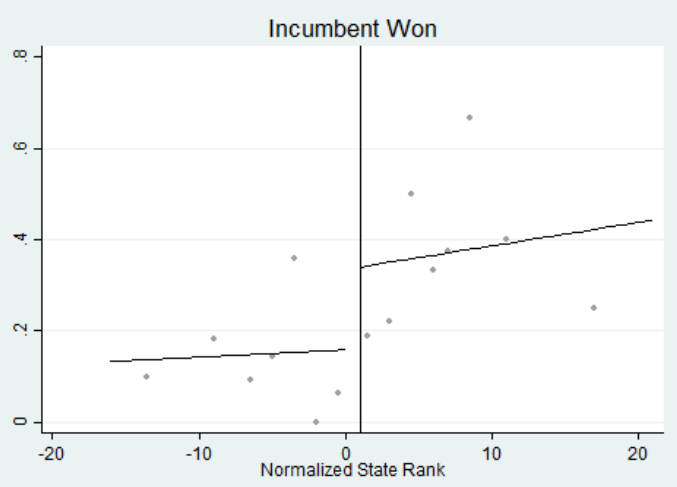

Note: The graphs use the optimal quantile-spaced binning procedure suggested by Calonico et al. (Forthcoming). Polynomials are fitted through the complete underlying dataset and not just the bins. 


\section{A Appendix}

Table A.8: Baseline Pre-Treatment Results (Phase 1 vs Phase 2)

\begin{tabular}{cccccccccc} 
& \multicolumn{3}{c}{ won constituencies } & \multicolumn{9}{c}{ vote share in percent } \\
& INC & UPA & Left & BJP & INC & UPA & Left & BJP & voter turnout \\
& $(1)$ & $(2)$ & $(3)$ & $(4)$ & $(5)$ & $(6)$ & $(7)$ & $(8)$ & $(9)$ \\
\hline $\begin{array}{c}\text { NREGS Phase 1 } \\
\text { (Linear) }\end{array}$ & -0.0673 & -0.0711 & 0.0212 & -0.0390 & $-7.20^{*}$ & $-7.48^{* *}$ & 0.38 & -0.51 & -0.0327 \\
& $(0.0819)$ & $(0.0865)$ & $(0.0340)$ & $(0.0731)$ & $(3.75)$ & $(3.64)$ & $(1.74)$ & $(3.21)$ & $(0.0247)$ \\
\hline $\begin{array}{c}\text { NREGS Phase 1 } \\
\text { (Linear flexible) }\end{array}$ & -0.0372 & -0.0474 & 0.0275 & -0.0344 & -4.42 & -5.01 & 0.76 & -0.89 & -0.0151 \\
\hline & $(0.0821)$ & $(0.0880)$ & $(0.0348)$ & $(0.0729)$ & $(3.71)$ & $(3.69)$ & $(1.79)$ & $(3.23)$ & $(0.0250)$ \\
NREGS Phase 1 & -0.0039 & -0.0108 & 0.0315 & -0.0140 & -1.55 & -1.74 & 1.05 & -0.34 & -0.0038 \\
(Quadratic) & $(0.0854)$ & $(0.0921)$ & $(0.0368)$ & $(0.0741)$ & $(3.86)$ & $(3.82)$ & $(1.88)$ & $(3.35)$ & $(0.0265)$ \\
\hline
\end{tabular}

\section{$\mathrm{N}$}

$378-378$ 378

378

378

$378 \quad 378 \quad 378$
378

Note: $* * * \mathrm{p}<0.01,{ }^{* *} \mathrm{p}<0.05, * \mathrm{p}<0.1$ Standard errors clustered at the district level in parentheses. An observation is an election constituency in the 2004 general election. Parametric regressions with different levels of flexibility are reported. Vote shares are given in percent. The won variables are indicator variables equal to 1 if a given party received a plurality of the votes in a constituency, and 0 otherwise. 
Table A.9: Baseline Pre-Treatment Results (Phase 2 vs Phase 3)

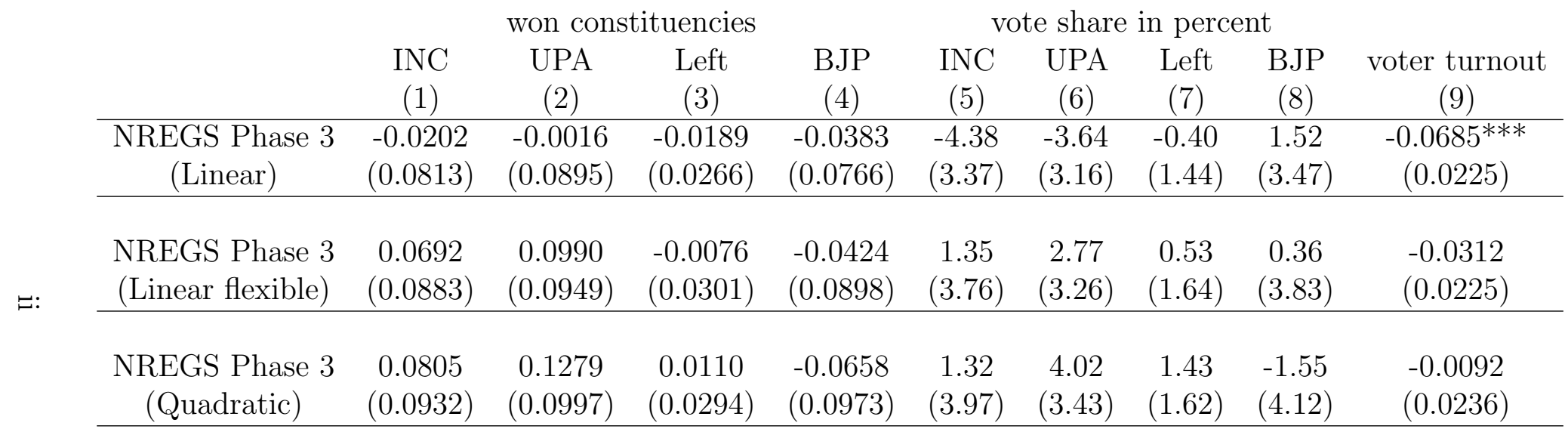

$\begin{array}{llllllllll}\mathrm{N} & 378 & 378 & 378 & 378 & 378 & 378 & 378 & 378 & 378\end{array}$

Note: ${ }^{* *} \mathrm{p}<0.01,{ }^{* *} \mathrm{p}<0.05,{ }^{*} \mathrm{p}<0.1$ Standard errors clustered at the district level in parentheses. An observation is an election constituency in the 2004 general election. Parametric regressions with different levels of flexibility are reported. Vote shares are given in percent. The won variables are indicator variables equal to 1 if a given party received a plurality of the votes in a constituency, and 0 otherwise. Star state is an indicator variable equal to 1 if a state was identified as a high implementation quality state, and 0 otherwise. The five star states are Andhra Pradesh, Chhattisgarh, Madhya Pradesh, Rajasthan and Tamil Nadu. 
Table A.10: Baseline Pre-Treatment Results Incumbent

incumbent Phase 1 vs 2 incumbent Phase 2 vs 3

won vote share won vote share

\begin{tabular}{ccccc} 
& $(1)$ & $(2)$ & $(3)$ & $(4)$ \\
\hline $\begin{array}{c}\text { NREGS } \\
\text { (Linear) }\end{array}$ & 0.0791 & 0.96 & -0.0525 & -3.03 \\
& $(0.0817)$ & $(3.35)$ & $(0.0833)$ & $(3.45)$ \\
\hline NREGS & 0.0797 & 1.21 & -0.0488 & -3.08 \\
(Linear flexible) & $(0.0842)$ & $(3.40)$ & $(0.0943)$ & $(3.92)$ \\
\hline & & & & \\
NREGS & 0.0966 & 1.52 & -0.0671 & -3.71 \\
(Quadratic) & $(0.0879)$ & $(3.53)$ & $(0.1003)$ & $(4.19)$ \\
\hline & & & & \\
$\mathrm{N}$ & 406 & 406 & 406 & 406 \\
\hline
\end{tabular}

Note: ${ }^{* * *} \mathrm{p}<0.01,{ }^{* *} \mathrm{p}<0.05,{ }^{*} \mathrm{p}<0.1$ Standard errors clustered at the district level in parentheses. An observation is an election constituency in the 2004 general election. Parametric regressions with different levels of flexibility are reported. Vote shares are given in percent. The won variables are indicator variables equal to 1 if a given party received a plurality of the votes in a constituency, and 0 otherwise. An incumbent is an individual who won a plurality of votes in his/her constituency in the 2004 general elections and who contested the 2009 elections in any constituency. 
Table A.11: Election Results Phase 1 vs Phase 2 (Full Sample)

\begin{tabular}{|c|c|c|c|c|c|c|c|c|c|}
\hline & & won con & tituencies & & & te share & in perc & & \\
\hline & $\begin{array}{l}\mathrm{INC} \\
(1)\end{array}$ & $\begin{array}{c}\text { UPA } \\
(2)\end{array}$ & $\begin{array}{c}\text { Left } \\
(3)\end{array}$ & $\begin{array}{c}\text { BJP } \\
(4)\end{array}$ & $\begin{array}{l}\mathrm{INC} \\
(5)\end{array}$ & $\begin{array}{c}\mathrm{UPA} \\
(6)\end{array}$ & $\begin{array}{c}\text { Left } \\
(7)\end{array}$ & $\begin{array}{c}\text { BJP } \\
(8)\end{array}$ & $\begin{array}{c}\text { voter turnout } \\
\text { (9) }\end{array}$ \\
\hline $\begin{array}{c}\text { NREGS Phase } 1 \\
\text { (Linear) }\end{array}$ & $\begin{array}{l}-0.1272 \\
(0.0818)\end{array}$ & $\begin{array}{r}-0.1382^{*} \\
(0.0836)\end{array}$ & $\begin{array}{r}0.0459^{* *} \\
(0.0228)\end{array}$ & $\begin{array}{l}-0.0595 \\
(0.0630)\end{array}$ & $\begin{array}{l}-5.45 \\
(3.48)\end{array}$ & $\begin{array}{l}-6.84^{*} \\
(3.51) \\
\end{array}$ & $\begin{array}{c}0.35 \\
(1.47) \\
\end{array}$ & $\begin{array}{l}-2.77 \\
(3.06)\end{array}$ & $\begin{array}{l}-0.0297 \\
(0.0288)\end{array}$ \\
\hline $\begin{array}{l}\text { NREGS Phase } 1 \\
\text { (Linear flexible) }\end{array}$ & $\begin{array}{l}-0.0823 \\
(0.0834)\end{array}$ & $\begin{array}{l}-0.0942 \\
(0.0852)\end{array}$ & $\begin{array}{l}0.0485^{*} \\
(0.0258)\end{array}$ & $\begin{array}{l}-0.0656 \\
(0.0632)\end{array}$ & $\begin{array}{l}-3.63 \\
(3.56)\end{array}$ & $\begin{array}{l}-5.58 \\
(3.58)\end{array}$ & $\begin{array}{c}0.67 \\
(1.53)\end{array}$ & $\begin{array}{l}-3.14 \\
(3.05)\end{array}$ & $\begin{array}{l}-0.0015 \\
(0.0284)\end{array}$ \\
\hline $\begin{array}{c}\text { NREGS Phase } 1 \\
\text { (Quadratic) }\end{array}$ & $\begin{array}{l}-0.0460 \\
(0.0871)\end{array}$ & $\begin{array}{l}-0.0426 \\
(0.0888)\end{array}$ & $\begin{array}{l}0.0529 * \\
(0.0274)\end{array}$ & $\begin{array}{l}-0.0658 \\
(0.0651)\end{array}$ & $\begin{array}{l}-1.74 \\
(3.72)\end{array}$ & $\begin{array}{l}-3.16 \\
(3.77)\end{array}$ & $\begin{array}{c}0.88 \\
(1.62)\end{array}$ & $\begin{array}{l}-2.94 \\
(3.16)\end{array}$ & $\begin{array}{c}0.0148 \\
(0.0304)\end{array}$ \\
\hline $\mathrm{N}$ & 406 & 406 & 406 & 406 & 406 & 406 & 406 & 406 & 406 \\
\hline
\end{tabular}

Note: ${ }^{* * *} \mathrm{p}<0.01,{ }^{* *} \mathrm{p}<0.05,{ }^{*} \mathrm{p}<0.1$ Standard errors clustered at the district level in parentheses. An observation is an election constituency in the 2009 general election. Parametric regressions with different levels of flexibility are reported. Vote shares are given in percent. The won variables are indicator variables equal to 1 if a given party received a plurality of the votes in a constituency, and 0 otherwise. 
Table A.12: Election Results Phase 2 vs Phase 3 (Full Sample)

\begin{tabular}{|c|c|c|c|c|c|c|c|c|c|}
\hline & & \multicolumn{3}{|c|}{ won constituencies } & \multicolumn{4}{|c|}{ vote share in percent } & \multirow[b]{2}{*}{$\begin{array}{c}\text { voter turnout } \\
\qquad(9)\end{array}$} \\
\hline & $\begin{array}{l}\mathrm{INC} \\
(1)\end{array}$ & $\begin{array}{c}\text { UPA } \\
(2)\end{array}$ & $\begin{array}{c}\text { Left } \\
(3)\end{array}$ & $\begin{array}{l}\text { BJP } \\
(4)\end{array}$ & $\begin{array}{l}\text { INC } \\
(5)\end{array}$ & $\begin{array}{c}\mathrm{UPA} \\
(6)\end{array}$ & $\begin{array}{l}\text { Left } \\
(7)\end{array}$ & $\begin{array}{c}\text { BJP } \\
(8)\end{array}$ & \\
\hline $\begin{array}{c}\text { NREGS Phase } 3 \\
\text { (Linear) }\end{array}$ & $\begin{array}{l}-0.0473 \\
(0.0819)\end{array}$ & $\begin{array}{l}-0.0150 \\
(0.0841)\end{array}$ & $\begin{array}{l}-0.0111 \\
(0.0152)\end{array}$ & $\begin{array}{l}-0.0032 \\
(0.0712)\end{array}$ & $\begin{array}{l}-0.75 \\
(3.33)\end{array}$ & $\begin{array}{c}2.04 \\
(3.13)\end{array}$ & $\begin{array}{l}-1.51 \\
(1.20)\end{array}$ & $\begin{array}{l}-0.02 \\
(3.20)\end{array}$ & $\begin{array}{c}-0.0916^{* * *} \\
(0.0247)\end{array}$ \\
\hline $\begin{array}{c}\text { NREGS Phase } 3 \\
\text { (Linear flexible) }\end{array}$ & $\begin{array}{c}0.0346 \\
(0.0901)\end{array}$ & $\begin{array}{c}0.0751 \\
(0.0934)\end{array}$ & $\begin{array}{l}-0.0114 \\
(0.0153)\end{array}$ & $\begin{array}{l}-0.0127 \\
(0.0809)\end{array}$ & $\begin{array}{l}2.90 \\
(3.59)\end{array}$ & $\begin{array}{l}6.24^{*} \\
(3.23)\end{array}$ & $\begin{array}{l}-0.89 \\
(1.25)\end{array}$ & $\begin{array}{l}-1.23 \\
(3.56)\end{array}$ & $\begin{array}{l}-0.0405^{*} \\
(0.0244)\end{array}$ \\
\hline $\begin{array}{c}\text { NREGS Phase } 3 \\
\text { (Quadratic) }\end{array}$ & $\begin{array}{c}0.0619 \\
(0.0957)\end{array}$ & $\begin{array}{c}0.1129 \\
(0.0988)\end{array}$ & $\begin{array}{c}0.0056 \\
(0.0145)\end{array}$ & $\begin{array}{l}-0.0571 \\
(0.0884)\end{array}$ & $\begin{array}{l}2.53 \\
(3.83) \\
\end{array}$ & $\begin{array}{l}6.22^{*} \\
(3.42)\end{array}$ & $\begin{array}{l}-0.14 \\
(1.30)\end{array}$ & $\begin{array}{l}-3.66 \\
(3.80) \\
\end{array}$ & $\begin{array}{l}-0.0166 \\
(0.0253)\end{array}$ \\
\hline $\mathrm{N}$ & 406 & 406 & 406 & 406 & 406 & 406 & 406 & 406 & 406 \\
\hline
\end{tabular}

Note: ${ }^{* * *} \mathrm{p}<0.01,{ }^{* *} \mathrm{p}<0.05,{ }^{*} \mathrm{p}<0.1$ Standard errors clustered at the district level in parentheses. An observation is an election constituency in the 2009 general election. Parametric regressions with different levels of flexibility are reported. Vote shares are given in percent. The won variables are indicator variables equal to 1 if a given party received a plurality of the votes in a constituency, and 0 otherwise. 
Table A.13: Star State Results Phase 1 vs Phase 2 (Full Sample)

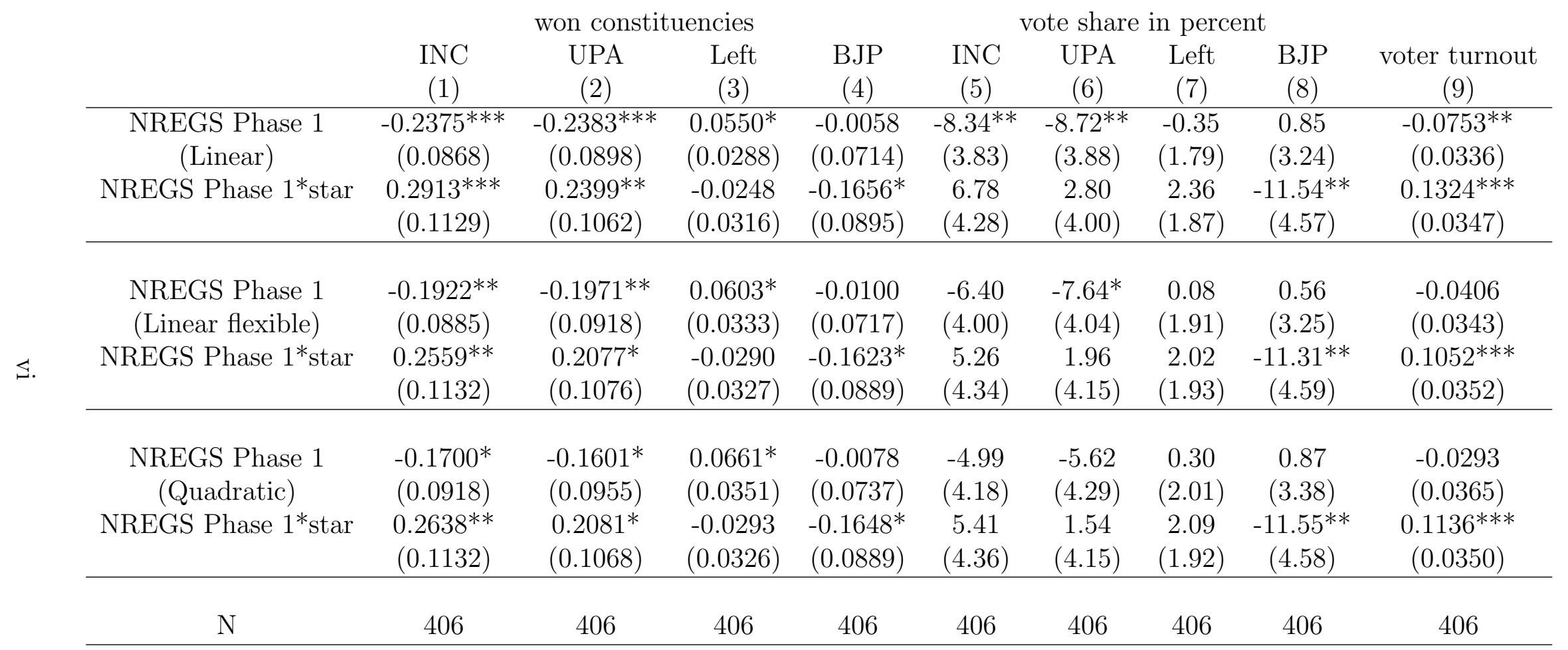

Note: ${ }^{* * *} \mathrm{p}<0.01,{ }^{* *} \mathrm{p}<0.05,{ }^{*} \mathrm{p}<0.1$ Standard errors clustered at the district level in parentheses. An observation is an election constituency in the 2009 general election. Parametric regressions with different levels of flexibility are reported. Vote shares are given in percent. The won variables are indicator variables equal to 1 if a given party received a plurality of the votes in a constituency, and 0 otherwise. Star state is an indicator variable equal to 1 if a state was identified as a high implementation quality state, and 0 otherwise. The five star states are Andhra Pradesh, Chhattisgarh, Madhya Pradesh, Rajasthan and Tamil Nadu. 
Table A.14: Star State Results Phase 2 vs Phase 3 (Full Sample)

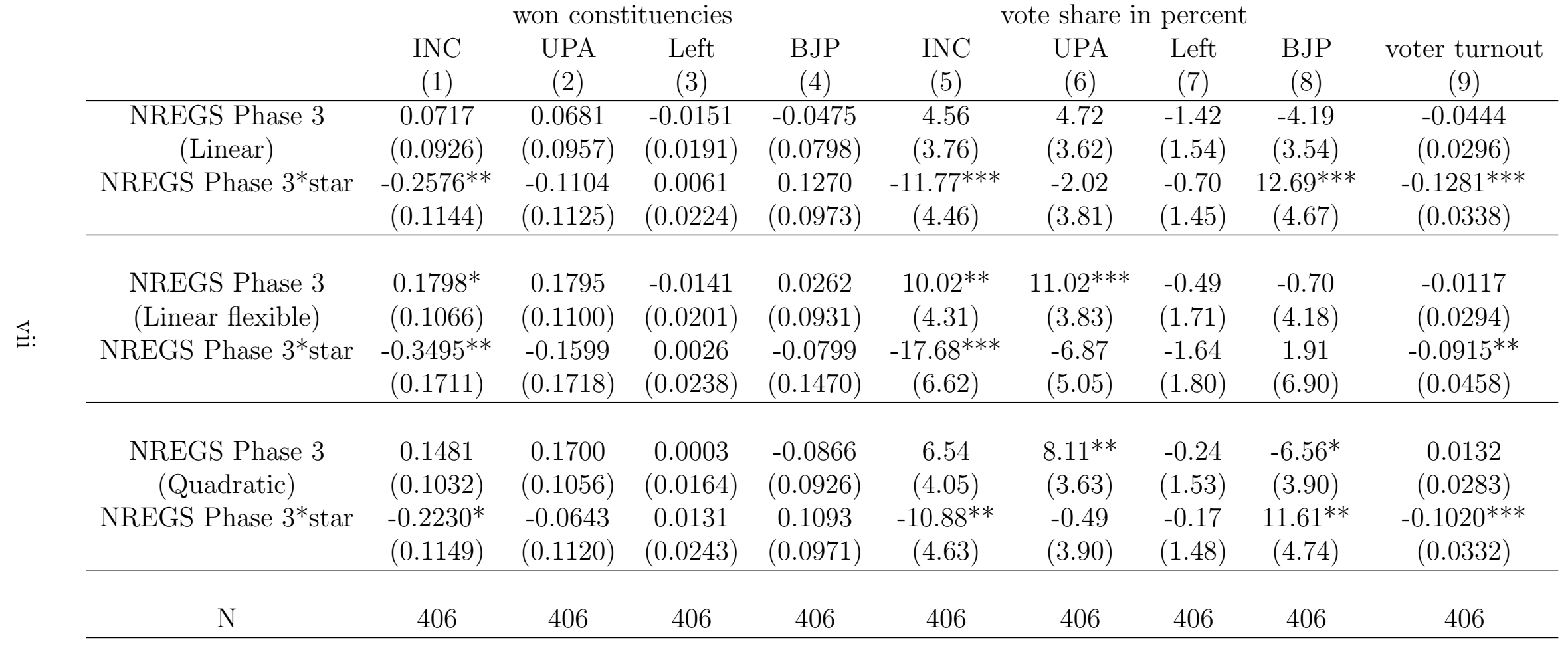

Note: $* * * \mathrm{p}<0.01,{ }^{* *} \mathrm{p}<0.05, * \mathrm{p}<0.1$ Standard errors clustered at the district level in parentheses. An observation is an election constituency in the 2009 general election. Parametric regressions with different levels of flexibility are reported. Vote shares are given in percent. The won variables are indicator variables equal to 1 if a given party received a plurality of the votes in a constituency, and 0 otherwise. 
Table A.15: Incumbent Results (Full Sample)

incumbent Phase 1 vs 2 incumbent Phase 2 vs 3

won vote share won vote share

\begin{tabular}{ccccc} 
& $(1)$ & $(2)$ & $(3)$ & $(4)$ \\
\hline $\begin{array}{c}\text { NREGS } \\
\text { (Linear) }\end{array}$ & $0.1455^{* *}$ & 1.65 & 0.0396 & 0.47 \\
& $(0.0724)$ & $(3.15)$ & $(0.0718)$ & $(3.32)$ \\
\hline NREGS & $0.1524^{* *}$ & 2.19 & 0.0349 & 1.35 \\
(Linear flexible) & $(0.0755)$ & $(3.32)$ & $(0.0797)$ & $(3.63)$ \\
\hline & & & & \\
NREGS & $0.1719^{* *}$ & 2.81 & 0.0579 & 1.26 \\
(Quadratic) & $(0.0784)$ & $(3.51)$ & $(0.0856)$ & $(3.85)$ \\
\hline $\mathrm{N}$ & 406 & 406 & 406 & 406 \\
\hline
\end{tabular}

Note: ${ }^{* * *} \mathrm{p}<0.01,{ }^{* *} \mathrm{p}<0.05,^{*} \mathrm{p}<0.1$ Standard errors clustered at the district level in parentheses. An observation is an election constituency in the 2009 general election. Parametric regressions with different levels of flexibility are reported. Vote shares are given in percent. The won variables are indicator variables equal to 1 if a given party received a plurality of the votes in a constituency, and 0 otherwise. An incumbent is an individual who won a plurality of votes in his/her constituency in the 2004 general elections and who contested the 2009 elections in any constituency. 
Table A.16: Incumbent Star Results (Full Sample)

incumbent Phase 1 vs 2 incumbent Phase 2 vs 3

\begin{tabular}{ccccc} 
& won & vote share & won & vote share \\
& $(1)$ & $(2)$ & $(3)$ & $(4)$ \\
\hline NREGS & 0.0767 & 0.43 & $0.1822^{* *}$ & 3.45 \\
(Linear) & $(0.0779)$ & $(3.51)$ & $(0.0811)$ & $(3.71)$ \\
NREGS*star & $0.1987^{*}$ & 3.40 & $-0.3884^{* * *}$ & $-8.05^{*}$ \\
& $(0.1117)$ & $(4.65)$ & $(0.1034)$ & $(4.61)$ \\
\hline & & & & \\
NREGS & 0.0662 & 0.42 & 0.1433 & 5.17 \\
(Linear flexible) & $(0.0828)$ & $(3.82)$ & $(0.0961)$ & $(4.21)$ \\
NREGS*star & $0.2901^{*}$ & 7.70 & $-0.3549^{* *}$ & -11.42 \\
& $(0.1702)$ & $(7.31)$ & $(0.1558)$ & $(7.27)$ \\
\hline & & & & \\
NREGS & 0.0960 & 1.57 & $0.1705^{*}$ & 3.57 \\
(Quadratic) & $(0.0854)$ & $(3.95)$ & $(0.0914)$ & $(4.10)$ \\
NREGS*star & $0.1908^{*}$ & 2.94 & $-0.3937^{* * *}$ & $-8.00^{*}$ \\
& $(0.1132)$ & $(4.70)$ & $(0.1051)$ & $(4.69)$ \\
\hline & \multicolumn{3}{c}{} \\
N & 406 & 406 & 406 & 406 \\
\hline
\end{tabular}

Note: ${ }^{* * *} \mathrm{p}<0.01,{ }^{* *} \mathrm{p}<0.05,{ }^{*} \mathrm{p}<0.1$ Standard errors clustered at the district level in parentheses. An observation is an election constituency in the 2009 general election. Parametric regressions with different levels of flexibility are reported. Vote shares are given in percent. The won variables are indicator variables equal to 1 if a given party received a plurality of the votes in a constituency, and 0 otherwise. 
Table A.17: Election Results: Probit specification won constituencies

\begin{tabular}{ccccccccc} 
& \multicolumn{4}{c}{ Phase 1 vs Phase 2} & \multicolumn{5}{c}{ Phase 2 vs Phase 3} \\
& INC & UPA & Left & BJP & INC & UPA & Left & BJP \\
& $(1)$ & $(2)$ & $(3)$ & $(4)$ & $(5)$ & $(6)$ & $(7)$ & $(8)$ \\
\hline NREGS & -0.1271 & $-0.1381^{*}$ & $0.0521^{*}$ & -0.0603 & -0.0506 & -0.0178 & -0.0166 & -0.0042 \\
(Linear) & $(0.0810)$ & $(0.0829)$ & $(0.0293)$ & $(0.0633)$ & $(0.0820)$ & $(0.0843)$ & $(0.0222)$ & $(0.0703)$ \\
\hline & & & & & & & & \\
NREGS & -0.0783 & -0.0916 & $0.0503^{* *}$ & -0.0682 & 0.0303 & 0.0710 & -0.0117 & -0.0106 \\
(Linear flexible) $)$ & $(0.0819)$ & $(0.0841)$ & $(0.0254)$ & $(0.0653)$ & $(0.0884)$ & $(0.0925)$ & $(0.0213)$ & $(0.0762)$ \\
\hline NREGS & -0.0394 & -0.0372 & $0.0491^{*}$ & -0.0679 & 0.0609 & 0.1110 & $0.0454^{*}$ & -0.0485 \\
$($ Quadratic) & $(0.0869)$ & $(0.0888)$ & $(0.0255)$ & $(0.0675)$ & $(0.0940)$ & $(0.0975)$ & $(0.0264)$ & $(0.0811)$ \\
\hline $\mathrm{N}$ & 406 & 406 & 406 & 406 & 406 & 406 & 406 & 406 \\
\hline
\end{tabular}

Note: ${ }^{* * *} \mathrm{p}<0.01,{ }^{* *} \mathrm{p}<0.05,{ }^{*} \mathrm{p}<0.1$ Standard errors clustered at the district level in parentheses. An observation is an election constituency in the 2009 general election. Parametric regressions with different levels of flexibility are reported. Vote shares are given in percent. The won variables are indicator variables equal to 1 if a given party received a plurality of the votes in a constituency, and 0 otherwise. 
Table A.18: Star State Results: Probit specification won constituencies

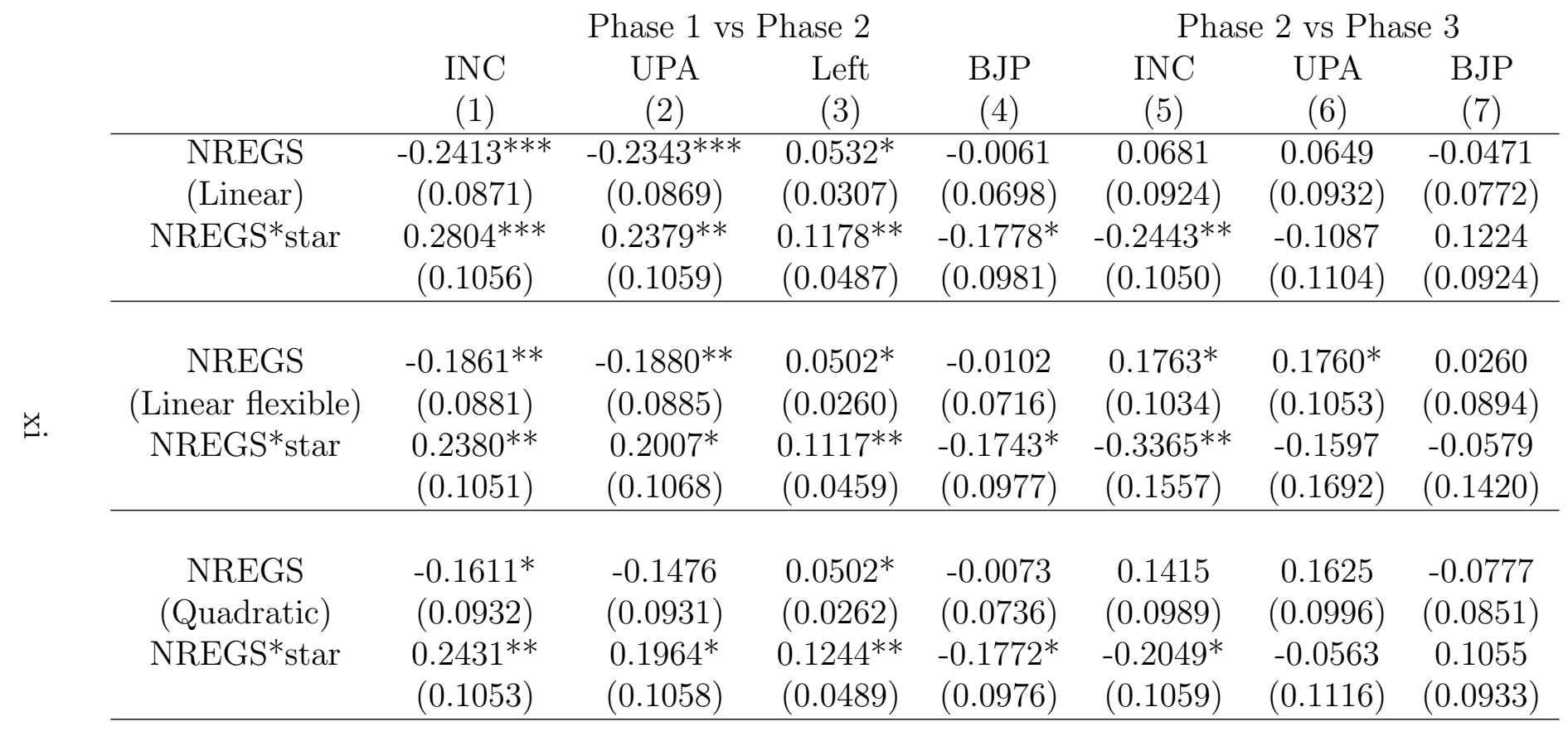

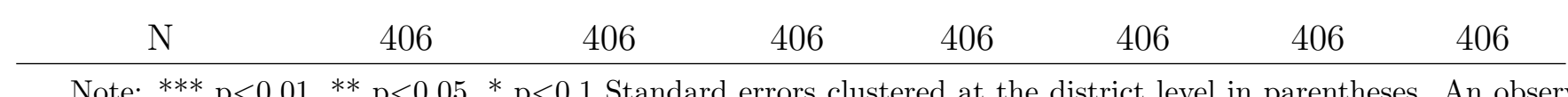

Standard errors clustered at the district level in parentheses. An observation is an election constituency in the 2009 general election. Parametric regressions with different levels of flexibility are reported. Vote shares are given in percent. The won variables are indicator variables equal to 1 if a given party received a plurality of the votes in a constituency, and 0 otherwise. 
Table A.19: Probit Incumbent Main and Star Results won constituencies incumbent Phase 1 vs 2 incumbent Phase 2 vs 3

\begin{tabular}{|c|c|c|c|c|}
\hline & $\begin{array}{c}\text { main } \\
(1)\end{array}$ & $\begin{array}{c}\text { star } \\
(2)\end{array}$ & $\begin{array}{c}\text { main } \\
(3)\end{array}$ & $\begin{array}{l}\text { star } \\
(4)\end{array}$ \\
\hline $\begin{array}{l}\text { NREGS } \\
\text { (Linear) }\end{array}$ & $\begin{array}{c}0.1460^{* *} \\
(0.0716)\end{array}$ & $\begin{array}{c}0.0783 \\
(0.0794)\end{array}$ & $\begin{array}{c}0.0397 \\
(0.0719)\end{array}$ & $\begin{array}{c}0.1809^{* *} \\
(0.0809)\end{array}$ \\
\hline NREGS* ${ }^{*}$ star & & $\begin{array}{l}0.1794^{*} \\
(0.1038)\end{array}$ & & $\begin{array}{c}-0.3767^{* * *} \\
(0.0988)\end{array}$ \\
\hline $\begin{array}{c}\text { NREGS } \\
\text { (Linear flexible) }\end{array}$ & $\begin{array}{c}0.1513^{* *} \\
(0.0731)\end{array}$ & $\begin{array}{c}0.0683 \\
(0.0836)\end{array}$ & $\begin{array}{c}0.0350 \\
(0.0791)\end{array}$ & $\begin{array}{c}0.1452 \\
(0.0920)\end{array}$ \\
\hline NREGS*star & & $\begin{array}{l}0.2549^{*} \\
(0.1501)\end{array}$ & & $\begin{array}{c}-0.3461^{* *} \\
(0.1585)\end{array}$ \\
\hline $\begin{array}{c}\text { NREGS } \\
\text { (Quadratic) }\end{array}$ & $\begin{array}{c}0.1715^{* *} \\
(0.0767)\end{array}$ & $\begin{array}{c}0.0983 \\
(0.0862)\end{array}$ & $\begin{array}{c}0.0578 \\
(0.0852)\end{array}$ & $\begin{array}{l}0.1689^{*} \\
(0.0907)\end{array}$ \\
\hline NREGS*star & & $\begin{array}{l}0.1719 \\
(0.1047)\end{array}$ & & $\begin{array}{c}-0.3823^{* * * *} \\
(0.1002)\end{array}$ \\
\hline $\mathrm{N}$ & 406 & 406 & 406 & 406 \\
\hline
\end{tabular}

Note: ${ }^{* * *} \mathrm{p}<0.01,{ }^{* *} \mathrm{p}<0.05,^{*} \mathrm{p}<0.1$ Standard errors clustered at the district level in parentheses. An observation is an election constituency in the 2009 general election. Parametric regressions with different levels of flexibility are reported. Vote shares are given in percent. The won variables are indicator variables equal to 1 if a given party received a plurality of the votes in a constituency, and 0 otherwise. 
Table A.20: Election Results Phase 1 vs Phase 2 (TOT)

\begin{tabular}{|c|c|c|c|c|c|c|c|c|c|}
\hline & \multicolumn{4}{|c|}{ won constituencies } & \multicolumn{4}{|c|}{ vote share in percent } & \multirow[b]{2}{*}{$\begin{array}{c}\text { voter turnout } \\
\qquad(9)\end{array}$} \\
\hline & $\begin{array}{l}\text { INC } \\
(1)\end{array}$ & $\begin{array}{c}\text { UPA } \\
(2)\end{array}$ & $\begin{array}{c}\text { Left } \\
(3)\end{array}$ & $\begin{array}{c}\text { BJP } \\
(4)\end{array}$ & $\begin{array}{l}\mathrm{INC} \\
(5)\end{array}$ & $\begin{array}{l}\mathrm{UPA} \\
(6)\end{array}$ & $\begin{array}{l}\text { Left } \\
(7)\end{array}$ & $\begin{array}{c}\text { BJP } \\
(8)\end{array}$ & \\
\hline $\begin{array}{c}\text { NREGS Phase } 1 \\
\text { (Linear) }\end{array}$ & $\begin{array}{l}-0.3332 \\
(0.2239)\end{array}$ & $\begin{array}{l}-0.3621 \\
(0.2283)\end{array}$ & $\begin{array}{l}0.1201^{*} \\
(0.0626)\end{array}$ & $\begin{array}{l}-0.1559 \\
(0.1717)\end{array}$ & $\begin{array}{l}-14.28 \\
(9.83)\end{array}$ & $\begin{array}{l}-17.93^{*} \\
(10.12)\end{array}$ & $\begin{array}{c}0.92 \\
(3.82)\end{array}$ & $\begin{array}{l}-7.25 \\
(8.29)\end{array}$ & $\begin{array}{l}-0.0778 \\
(0.0768)\end{array}$ \\
\hline $\begin{array}{c}\text { NREGS Phase } 1 \\
\text { (Linear flexible) }\end{array}$ & $\begin{array}{l}-0.2581 \\
(0.2543)\end{array}$ & $\begin{array}{l}-0.2933 \\
(0.2596)\end{array}$ & $\begin{array}{l}0.1442^{*} \\
(0.0797)\end{array}$ & $\begin{array}{l}-0.1944 \\
(0.1989)\end{array}$ & $\begin{array}{l}-11.34 \\
(11.13)\end{array}$ & $\begin{array}{l}-17.02 \\
(11.58)\end{array}$ & $\begin{array}{c}1.91 \\
(4.48)\end{array}$ & $\begin{array}{l}-9.28 \\
(9.53)\end{array}$ & $\begin{array}{l}-0.0122 \\
(0.0854)\end{array}$ \\
\hline $\begin{array}{c}\text { NREGS Phase } 1 \\
\text { (Quadratic) }\end{array}$ & $\begin{array}{l}-0.1573 \\
(0.3002)\end{array}$ & $\begin{array}{l}-0.1457 \\
(0.3044)\end{array}$ & $\begin{array}{l}0.1809^{*} \\
(0.1018)\end{array}$ & $\begin{array}{l}-0.2248 \\
(0.2419)\end{array}$ & $\begin{array}{c}-5.94 \\
(12.97)\end{array}$ & $\begin{array}{l}-10.80 \\
(13.46)\end{array}$ & $\begin{array}{c}3.01 \\
(5.44)\end{array}$ & $\begin{array}{l}-10.04 \\
(11.52)\end{array}$ & $\begin{array}{c}0.0508 \\
(0.1030)\end{array}$ \\
\hline $\mathrm{N}$ & 406 & 406 & 406 & 406 & 406 & 406 & 406 & 406 & 406 \\
\hline
\end{tabular}

Note: ${ }^{* * *} \mathrm{p}<0.01,{ }^{* *} \mathrm{p}<0.05,{ }^{*} \mathrm{p}<0.1$ Standard errors clustered at the district level in parentheses. An observation is an election constituency in the 2009 general election. Parametric regressions with different levels of flexibility are reported. Vote shares are given in percent. The won variables are indicator variables equal to 1 if a given party received a plurality of the votes in a constituency, and 0 otherwise. 
Table A.21: Election Results Phase 2 vs Phase 3 (TOT)

\begin{tabular}{|c|c|c|c|c|c|c|c|c|c|}
\hline & \multicolumn{4}{|c|}{ won constituencies } & \multicolumn{4}{|c|}{ vote share in percent } & \multirow[b]{2}{*}{$\begin{array}{c}\text { voter turnout } \\
\text { (9) }\end{array}$} \\
\hline & $\begin{array}{l}\text { INC } \\
(1)\end{array}$ & $\begin{array}{c}\text { UPA } \\
(2)\end{array}$ & $\begin{array}{c}\text { Left } \\
(3)\end{array}$ & $\begin{array}{c}\text { BJP } \\
(4)\end{array}$ & $\begin{array}{l}\mathrm{INC} \\
(5)\end{array}$ & $\begin{array}{c}\mathrm{UPA} \\
(6)\end{array}$ & $\begin{array}{l}\text { Left } \\
(7)\end{array}$ & $\begin{array}{c}\text { BJP } \\
(8)\end{array}$ & \\
\hline $\begin{array}{c}\text { NREGS Phase } 3 \\
\text { (Linear) }\end{array}$ & $\begin{array}{l}-0.1348 \\
(0.2358)\end{array}$ & $\begin{array}{l}-0.0429 \\
(0.2400)\end{array}$ & $\begin{array}{l}-0.0315 \\
(0.0431)\end{array}$ & $\begin{array}{l}-0.0090 \\
(0.2021)\end{array}$ & $\begin{array}{l}-2.13 \\
(9.46)\end{array}$ & $\begin{array}{c}5.82 \\
(8.80)\end{array}$ & $\begin{array}{l}-4.30 \\
(3.45)\end{array}$ & $\begin{array}{l}-0.06 \\
(9.10)\end{array}$ & $\begin{array}{c}-0.2611^{* * *} \\
(0.0805)\end{array}$ \\
\hline $\begin{array}{c}\text { NREGS Phase } 3 \\
\text { (Linear flexible) }\end{array}$ & $\begin{array}{c}0.1128 \\
(0.2559)\end{array}$ & $\begin{array}{c}0.2296 \\
(0.2648)\end{array}$ & $\begin{array}{l}-0.0324 \\
(0.0440)\end{array}$ & $\begin{array}{l}-0.0380 \\
(0.2317)\end{array}$ & $\begin{array}{c}8.90 \\
(10.45)\end{array}$ & $\begin{array}{l}18.53^{*} \\
(9.72)\end{array}$ & $\begin{array}{l}-2.45 \\
(3.61)\end{array}$ & $\begin{array}{c}-3.71 \\
(10.17)\end{array}$ & $\begin{array}{l}-0.1068 \\
(0.0765)\end{array}$ \\
\hline $\begin{array}{c}\text { NREGS Phase } 3 \\
\text { (Quadratic) }\end{array}$ & $\begin{array}{c}0.2343 \\
(0.3648)\end{array}$ & $\begin{array}{c}0.4272 \\
(0.3832)\end{array}$ & $\begin{array}{c}0.0211 \\
(0.0554)\end{array}$ & $\begin{array}{l}-0.2161 \\
(0.3322)\end{array}$ & $\begin{array}{c}9.56 \\
(15.01)\end{array}$ & $\begin{array}{c}23.54 \\
(14.45)\end{array}$ & $\begin{array}{l}-0.54 \\
(4.88)\end{array}$ & $\begin{array}{l}-13.85 \\
(14.54)\end{array}$ & $\begin{array}{l}-0.0627 \\
(0.0955)\end{array}$ \\
\hline $\mathrm{N}$ & 406 & 406 & 406 & 406 & 406 & 406 & 406 & 406 & 406 \\
\hline
\end{tabular}

Note: ${ }^{* * *} \mathrm{p}<0.01,{ }^{* *} \mathrm{p}<0.05,{ }^{*} \mathrm{p}<0.1$ Standard errors clustered at the district level in parentheses. An observation is an election constituency in the 2009 general election. Parametric regressions with different levels of flexibility are reported. Vote shares are given in percent. The won variables are indicator variables equal to 1 if a given party received a plurality of the votes in a constituency, and 0 otherwise. 
Table A.22: Star State Results Phase 1 vs Phase 2 (TOT)

won constituencies $\quad$ vote share in percent

\begin{tabular}{cccccccccc} 
& INC & UPA & Left & BJP & INC & UPA & Left & BJP & voter turnout \\
& $(1)$ & $(2)$ & $(3)$ & $(4)$ & $(5)$ & $(6)$ & $(7)$ & $(8)$ & $(9)$ \\
\hline NREGS Phase 1 & $-0.5399^{* *}$ & $-0.5550^{* *}$ & $0.1360^{*}$ & -0.0574 & $-19.85^{*}$ & $-21.82^{* *}$ & -0.31 & -0.75 & $-0.1611^{*}$ \\
(Linear) & $(0.2488)$ & $(0.2501)$ & $(0.0697)$ & $(0.1791)$ & $(10.68)$ & $(10.68)$ & $(4.32)$ & $(8.24)$ & $(0.0909)$ \\
NREGS Phase 1*star & $0.4715^{* *}$ & $0.3824^{* *}$ & -0.0354 & $-0.2875^{*}$ & 10.58 & 3.64 & 4.03 & $-19.86^{* *}$ & $0.2188^{* * *}$ \\
& $(0.1943)$ & $(0.1794)$ & $(0.0572)$ & $(0.1695)$ & $(7.51)$ & $(7.63)$ & $(3.11)$ & $(8.86)$ & $(0.0617)$ \\
\hline
\end{tabular}

$\begin{array}{cccccccccc}\text { NREGS Phase 1 } & -0.5137^{*} & -0.5442^{*} & 0.1725^{*} & -0.0863 & -18.41 & -23.05^{*} & 0.80 & -2.17 & -0.0993 \\ \text { (Linear flexible) } & (0.2931) & (0.2964) & (0.0922) & (0.2113) & (12.61) & (12.83) & (5.29) & (9.69) & (0.1061) \\ \text { NREGS Phase 1*star } & 0.4610^{* *} & 0.3781^{* *} & -0.0499 & -0.2759 & 10.01 & 4.13 & 3.59 & -19.30^{* *} & 0.1942^{* * *} \\ & (0.2004) & (0.1876) & (0.0601) & (0.1697) & (7.83) & (7.99) & (3.31) & (8.81) & (0.0658)\end{array}$

\begin{tabular}{cccccccccc} 
NREGS Phase 1 & -0.4849 & -0.4750 & $0.2217^{*}$ & -0.1027 & -15.29 & -19.28 & 2.01 & -2.15 & -0.0526 \\
(Quadratic) & $(0.3507)$ & $(0.3504)$ & $(0.1195)$ & $(0.2581)$ & $(14.98)$ & $(15.40)$ & $(6.47)$ & $(11.89)$ & $(0.1254)$ \\
NREGS Phase 1*star & $0.4589^{* *}$ & $0.3642^{*}$ & -0.0550 & -0.2771 & 9.54 & 3.06 & 3.50 & $-19.54^{* *}$ & $0.1940^{* * *}$ \\
& $(0.2027)$ & $(0.1885)$ & $(0.0654)$ & $(0.1712)$ & $(7.86)$ & $(8.00)$ & $(3.39)$ & $(8.85)$ & $(0.0671)$ \\
\hline
\end{tabular}

\begin{tabular}{llllllllll}
$\mathrm{N}$ & 406 & 406 & 406 & 406 & 406 & 406 & 406 & 406 & 406 \\
\hline
\end{tabular}

Note: ${ }^{* * *} \mathrm{p}<0.01,{ }^{* *} \mathrm{p}<0.05,{ }^{*} \mathrm{p}<0.1$ Standard errors clustered at the district level in parentheses. An observation is an election constituency in the 2009 general election. Parametric regressions with different levels of flexibility are reported. Vote shares are given in percent. The won variables are indicator variables equal to 1 if a given party received a plurality of the votes in a constituency, and 0 otherwise. 
Table A.23: Star State Results Phase 2 vs Phase 3 (TOT)

\begin{tabular}{|c|c|c|c|c|c|c|c|c|c|}
\hline & & won const & ituencies & & & e share & percen & & \\
\hline & $\begin{array}{l}\text { INC } \\
(1)\end{array}$ & $\begin{array}{c}\text { UPA } \\
(2)\end{array}$ & $\begin{array}{l}\text { Left } \\
(3)\end{array}$ & $\begin{array}{l}\text { BJP } \\
(4)\end{array}$ & $\begin{array}{c}\text { INC } \\
(5)\end{array}$ & $\begin{array}{l}\text { UPA } \\
(6)\end{array}$ & $\begin{array}{l}\text { Left } \\
(7)\end{array}$ & $\begin{array}{l}\text { BJP } \\
(8)\end{array}$ & $\begin{array}{c}\text { voter turnout } \\
\qquad(9)\end{array}$ \\
\hline $\begin{array}{c}\text { NREGS Phase } 3 \\
\text { (Linear) }\end{array}$ & $\begin{array}{c}0.1304 \\
(0.2470)\end{array}$ & $\begin{array}{c}0.1617 \\
(0.2543)\end{array}$ & $\begin{array}{l}-0.0412 \\
(0.0503)\end{array}$ & $\begin{array}{l}-0.0987 \\
(0.2164)\end{array}$ & $\begin{array}{c}9.60 \\
(10.16)\end{array}$ & $\begin{array}{l}12.79 \\
(9.59)\end{array}$ & $\begin{array}{l}-4.22 \\
(4.07)\end{array}$ & $\begin{array}{l}-8.28 \\
(9.86)\end{array}$ & $\begin{array}{c}-0.1620^{* *} \\
(0.0804)\end{array}$ \\
\hline NREGS Phase $3^{*}$ star & $\begin{array}{c}-0.4330^{* *} \\
(0.1925)\end{array}$ & $\begin{array}{l}-0.1753 \\
(0.1836)\end{array}$ & $\begin{array}{c}0.0065 \\
(0.0360)\end{array}$ & $\begin{array}{c}0.2102 \\
(0.1647)\end{array}$ & $\begin{array}{c}-19.44^{* * *} \\
(7.33)\end{array}$ & $\begin{array}{l}-2.26 \\
(6.09)\end{array}$ & $\begin{array}{l}-1.63 \\
(2.33)\end{array}$ & $\begin{array}{c}21.15^{* *} \\
(8.36)\end{array}$ & $\begin{array}{c}-0.2373^{* * *} \\
(0.0877)\end{array}$ \\
\hline $\begin{array}{c}\text { NREGS Phase } 3 \\
\text { (Linear flexible) } \\
\text { NREGS Phase } 3{ }^{*} \text { star }\end{array}$ & $\begin{array}{c}0.3244 \\
(0.2691) \\
-0.3862^{* *} \\
(0.1907)\end{array}$ & $\begin{array}{c}0.4188 \\
(0.2785) \\
-0.1134 \\
(0.1843)\end{array}$ & $\begin{array}{c}-0.0421 \\
(0.0506) \\
0.0063 \\
(0.0355)\end{array}$ & $\begin{array}{c}-0.0998 \\
(0.2418) \\
0.2099 \\
(0.1654)\end{array}$ & $\begin{array}{c}18.21 \\
(11.29) \\
-17.36^{* *} \\
(7.62)\end{array}$ & $\begin{array}{c}25.54^{* *} \\
(10.46) \\
0.81 \\
(6.90)\end{array}$ & $\begin{array}{l}-2.72 \\
(4.10) \\
-1.27 \\
(2.27)\end{array}$ & $\begin{array}{c}-8.99 \\
(10.82) \\
20.97^{* *} \\
(8.60)\end{array}$ & $\begin{array}{c}-0.0435 \\
(0.0858) \\
-0.2087^{* * *} \\
(0.0758)\end{array}$ \\
\hline $\begin{array}{c}\text { NREGS Phase } 3 \\
\text { (Quadratic) } \\
\text { NREGS Phase } 3 * \text { star }\end{array}$ & $\begin{array}{l}0.4235 \\
(0.3776) \\
-0.3270 \\
(0.1994)\end{array}$ & $\begin{array}{c}0.6052 \\
(0.4045) \\
-0.0149 \\
(0.1962)\end{array}$ & $\begin{array}{c}0.0092 \\
(0.0558) \\
0.0247 \\
(0.0414)\end{array}$ & $\begin{array}{c}-0.2609 \\
(0.3393) \\
0.1515 \\
(0.1695)\end{array}$ & $\begin{array}{c}18.05 \\
(15.59) \\
-16.38^{* *} \\
(8.22)\end{array}$ & $\begin{array}{c}30.46^{* *} \\
(15.37) \\
4.13 \\
(7.75)\end{array}$ & $\begin{array}{l}-1.01 \\
(5.17) \\
-0.47 \\
(2.20)\end{array}$ & $\begin{array}{c}-17.69 \\
(15.18) \\
17.74^{* *} \\
(8.58)\end{array}$ & $\begin{array}{c}-0.0133 \\
(0.1065) \\
-0.1835^{* *} \\
(0.0727)\end{array}$ \\
\hline
\end{tabular}

\begin{tabular}{llllllllll}
$\mathrm{N}$ & 406 & 406 & 406 & 406 & 406 & 406 & 406 & 406 & 406 \\
\hline
\end{tabular}

Note: $* * * \mathrm{p}<0.01, * * \mathrm{p}<0.05,{ }^{*} \mathrm{p}<0.1$ Standard errors clustered at the district level in parentheses. An observation is an election constituency in the 2009 general election. Parametric regressions with different levels of flexibility are reported. Vote shares are given in percent. The won variables are indicator variables equal to 1 if a given party received a plurality of the votes in a constituency, and 0 otherwise. 
Table A.24: Incumbent Results (TOT)

incumbent Phase 1 vs 2 incumbent Phase 2 vs 3

won vote share won vote share

\begin{tabular}{ccccc} 
& $(1)$ & $(2)$ & $(3)$ & $(4)$ \\
\hline NREGS & $0.3812^{* *}$ & 4.32 & 0.1130 & 1.34 \\
$($ Linear $)$ & $(0.1939)$ & $(8.22)$ & $(0.2076)$ & $(9.48)$ \\
\hline & & & & \\
NREGS & $0.4534^{*}$ & 6.40 & 0.0989 & 4.00 \\
(Linear flexible) & $(0.2319)$ & $(9.74)$ & $(0.2310)$ & $(10.54)$ \\
\hline & & & & \\
NREGS & $0.5876^{* *}$ & 9.61 & 0.2189 & 4.76 \\
(Quadratic) & $(0.2989)$ & $(12.07)$ & $(0.3383)$ & $(14.85)$ \\
\hline $\mathrm{N}$ & 406 & 406 & 406 & 406 \\
\hline
\end{tabular}

Note: ${ }^{* * *} \mathrm{p}<0.01,{ }^{* *} \mathrm{p}<0.05,{ }^{*} \mathrm{p}<0.1$ Standard errors clustered at the district level in parentheses. An observation is an election constituency in the 2009 general election. Parametric regressions with different levels of flexibility are reported. Vote shares are given in percent. The won variables are indicator variables equal to 1 if a given party received a plurality of the votes in a constituency, and 0 otherwise. An incumbent is an individual who won a plurality of votes in his/her constituency in the 2004 general elections and who contested the 2009 elections in any constituency. 
Table A.25: Incumbent Star Results (TOT)

incumbent Phase 1 vs 2 incumbent Phase 2 vs 3

\begin{tabular}{ccccc} 
& won & vote share & won & vote share \\
& $(1)$ & $(2)$ & $(3)$ & $(4)$ \\
\hline NREGS & 0.2490 & 1.97 & $0.4067^{*}$ & 7.51 \\
(Linear) & $(0.1875)$ & $(8.54)$ & $(0.2411)$ & $(10.25)$ \\
NREGS*star & 0.3545 & 5.95 & $-0.6325^{* * *}$ & $-13.20^{*}$ \\
& $(0.2259)$ & $(8.08)$ & $(0.1753)$ & $(7.68)$ \\
\hline & & & & \\
NREGS & 0.3075 & 3.98 & 0.3149 & 8.46 \\
(Linear flexible) & $(0.2320)$ & $(10.54)$ & $(0.2589)$ & $(11.21)$ \\
NREGS*star & 0.3312 & 5.15 & $-0.6547^{* * *}$ & $-12.97^{*}$ \\
& $(0.2265)$ & $(8.22)$ & $(0.1822)$ & $(7.83)$ \\
\hline & & & & \\
NREGS & 0.4281 & 6.91 & 0.4025 & 8.60 \\
(Quadratic) & $(0.2940)$ & $(13.10)$ & $(0.3695)$ & $(15.29)$ \\
NREGS*star & 0.3136 & 4.82 & $-0.6341^{* * *}$ & -12.81 \\
& $(0.2371)$ & $(8.38)$ & $(0.1871)$ & $(8.29)$ \\
\hline & \multicolumn{3}{c}{} \\
N & 406 & 406 & 406 & 406 \\
\hline
\end{tabular}

Note: ${ }^{* * *} \mathrm{p}<0.01,{ }^{* *} \mathrm{p}<0.05,^{*} \mathrm{p}<0.1$ Standard errors clustered at the district level in parentheses. An observation is an election constituency in the 2009 general election. Parametric regressions with different levels of flexibility are reported. Vote shares are given in percent. The won variables are indicator variables equal to 1 if a given party received a plurality of the votes in a constituency, and 0 otherwise. 
Table A.26: Star State Results DID Specification

\begin{tabular}{|c|c|c|c|c|c|c|c|c|c|}
\hline & & won $\mathrm{co}$ & tituencie & & & te share in & percent & & \\
\hline $\begin{array}{c}\text { NREGS Phase } 1 \\
\text { (Linear) }\end{array}$ & $\begin{array}{l}-0.0567 \\
(0.0647)\end{array}$ & $\begin{array}{l}-0.1398^{*} \\
(0.0725)\end{array}$ & $\begin{array}{c}0.0023 \\
(0.0146)\end{array}$ & $\begin{array}{l}0.0860^{*} \\
(0.0513)\end{array}$ & $\begin{array}{c}-7.90^{* * *} \\
(2.32)\end{array}$ & $\begin{array}{c}-6.56^{* * *} \\
(2.37)\end{array}$ & $\begin{array}{c}1.18 \\
(1.17)\end{array}$ & $\begin{array}{c}-4.16^{* *} \\
(2.09)\end{array}$ & $\begin{array}{c}-0.0287^{* * *} \\
(0.0098)\end{array}$ \\
\hline NREGS Phase $1 *$ star & $\begin{array}{c}0.1635 \\
(0.1036)\end{array}$ & $\begin{array}{c}0.1283 \\
(0.1061)\end{array}$ & $\begin{array}{c}0.0101 \\
(0.0089)\end{array}$ & $\begin{array}{c}-0.1506^{* *} \\
(0.0685)\end{array}$ & $\begin{array}{c}13.55^{* * *} \\
(2.97)\end{array}$ & $\begin{array}{c}14.59^{* * *} \\
(3.08)\end{array}$ & $\begin{array}{c}0.29 \\
(1.68)\end{array}$ & $\begin{array}{l}-4.24 \\
(3.28)\end{array}$ & $\begin{array}{c}0.0772^{* * *} \\
(0.0134)\end{array}$ \\
\hline $\mathrm{N}$ & 784 & 784 & 784 & 784 & 784 & 784 & 784 & 784 & 784 \\
\hline
\end{tabular}

Note: ${ }^{* * *} \mathrm{p}<0.01,{ }^{* *} \mathrm{p}<0.05,{ }^{*} \mathrm{p}<0.1$ Standard errors clustered at the district level in parentheses. An observation is an election constituency in the 2009 general election. Parametric regressions with different levels of flexibility are reported. Vote shares are given in percent. The won variables are indicator variables equal to 1 if a given party received a plurality of the votes in a constituency, and 0 otherwise. 
Table A.27: Financial Allocation Star State Results (2008/2009)

Phase 1 vs Phase $2 \quad$ Phase 2 vs Phase 3

centr. rel. tot. funds tot. exp. admin exp. centr. rel. tot. funds tot. exp. admin exp.

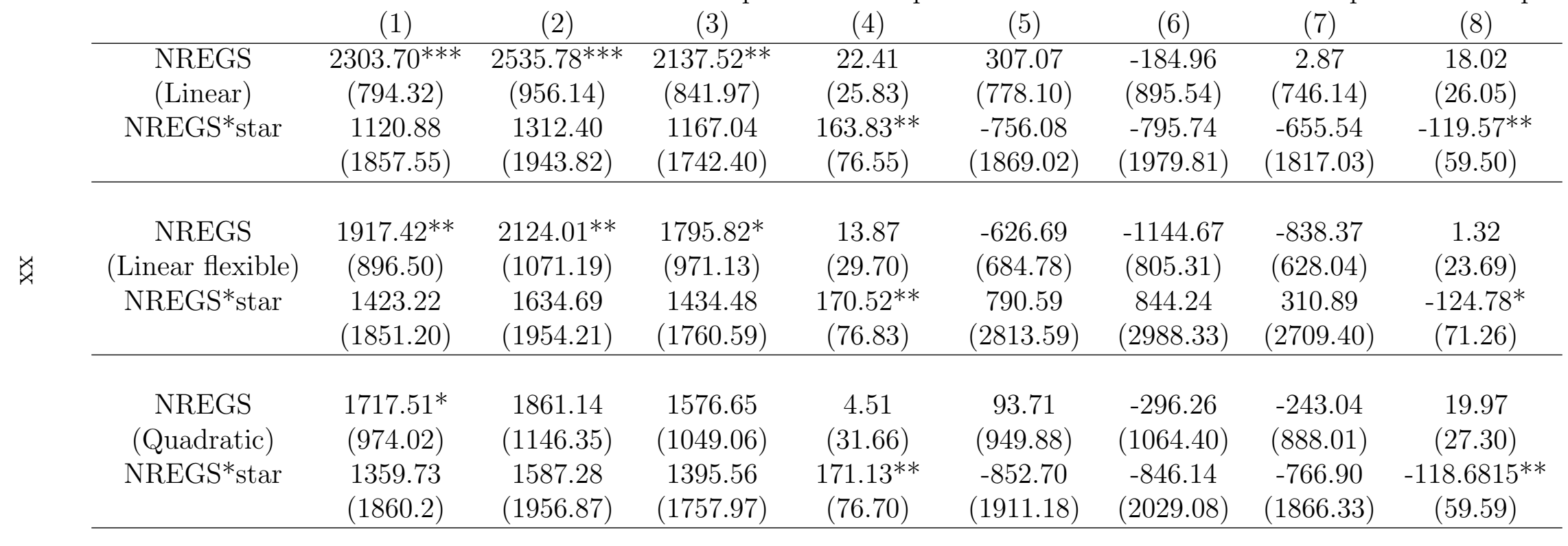

\begin{tabular}{lllllllll}
$\mathrm{N}$ & 406 & 406 & 406 & 406 & 406 & 406 & 406 & 406 \\
\hline
\end{tabular}

Note: ${ }^{* *} \mathrm{p}<0.01,{ }^{* *} \mathrm{p}<0.05,{ }^{*} \mathrm{p}<0.1$ Standard errors clustered at the district level in parentheses. An observation is an election constituency in the 2009 general election. Parametric regressions with different levels of flexibility are reported. 
Table A.28: Other Star State Results Phase 1 vs Phase 2

\begin{tabular}{|c|c|c|c|c|c|c|}
\hline & $\begin{array}{c}\text { pers.empl } 1 \\
\text { (1) }\end{array}$ & $\begin{array}{c}\text { pub empl } \\
(2)\end{array}$ & $\begin{array}{c}\text { priv } \\
(3)\end{array}$ & $\begin{array}{c}\text { fam } \\
(4)\end{array}$ & $\begin{array}{c}\text { log wage } \\
(5)\end{array}$ & $\begin{array}{c}\text { per cap cons } \\
(6)\end{array}$ \\
\hline NREGS Phase 1 & $72364.88^{* *}$ & 0.0009 & 0.0093 & 0.0189 & $-0.0921^{*}$ & $-0.1654^{* * *}$ \\
\hline (Linear) & $(35931.21)$ & $(0.0041)$ & $(0.0261)$ & $(0.0271)$ & $(0.0536)$ & $(0.0440)$ \\
\hline NREGS Phase $1{ }^{*}$ star & $-132107.3^{* * *}$ & 0.0135 & -0.0245 & -0.0146 & $0.1829 * *$ & $0.1188 * *$ \\
\hline & $(41397.96)$ & $(0.0094)$ & $(0.0387)$ & $(0.0424)$ & $(0.0794)$ & $(0.0600)$ \\
\hline NREGS Phase 1 & $85938.63^{* *}$ & -0.0031 & 0.0268 & -0.0076 & -0.0790 & $-0.1377^{* * *}$ \\
\hline (Linear flexible) & $(41308.33)$ & $(0.0047)$ & $(0.0279)$ & $(0.0287)$ & $(0.0566)$ & $(0.0463)$ \\
\hline NREGS Phase $1{ }^{*}$ star & $-142731.3^{* * *}$ & $0.0167^{*}$ & -0.0384 & 0.0065 & $0.1722^{* *}$ & 0.0969 \\
\hline & $(44070.06)$ & $(0.0096)$ & $(0.0387)$ & $(0.0422)$ & $(0.0808)$ & $(0.0615)$ \\
\hline NREGS Phase 1 & $87078.83^{* *}$ & -0.0041 & 0.0285 & -0.0148 & -0.0737 & $-0.1160 * *$ \\
\hline (Quadratic) & $(44201.16)$ & $(0.0053)$ & $(0.0291)$ & $(0.0300)$ & $(0.0590)$ & $(0.0484)$ \\
\hline NREGS Phase $1{ }^{*}$ star & $-138102.6^{* * *}$ & $0.0158^{*}$ & -0.0332 & 0.0007 & $0.1744^{* *}$ & 0.0964 \\
\hline & $(43097.58)$ & $(0.0095)$ & $(0.0389)$ & $(0.0424)$ & $(0.0806)$ & $(0.0610)$ \\
\hline
\end{tabular}

\begin{tabular}{lllllll}
$\mathrm{N}$ & 406 & 418 & 418 & 418 & 418 & 418 \\
\hline
\end{tabular}

Note: ${ }^{* * *} \mathrm{p}<0.01,{ }^{* *} \mathrm{p}<0.05,{ }^{*} \mathrm{p}<0.1$ Standard errors clustered at the district level in parentheses. An observation is an election constituency in the 2009 general election. Parametric regressions with different levels of flexibility are reported. 
Table A.29: Other Star State Results Phase 2 vs Phase 3

\begin{tabular}{|c|c|c|c|c|c|c|}
\hline & $\begin{array}{c}\text { pers.empl } \\
(1) \\
\end{array}$ & $\begin{array}{c}\text { pub empl } \\
(2)\end{array}$ & $\begin{array}{c}\text { priv } \\
(3)\end{array}$ & $\begin{array}{c}\text { fam } \\
(4)\end{array}$ & $\begin{array}{c}\text { log wage } \\
(5) \\
\end{array}$ & $\begin{array}{c}\text { per cap cons } \\
(6)\end{array}$ \\
\hline $\begin{array}{c}\text { NREGS Phase } 3 \\
\text { (Linear) }\end{array}$ & $\begin{array}{c}-73588.23^{* * *} \\
(24819.73)\end{array}$ & $\begin{array}{c}0.0029 \\
(0.0041)\end{array}$ & $\begin{array}{l}-0.0176 \\
(0.0261)\end{array}$ & $\begin{array}{l}-0.0080 \\
(0.0280)\end{array}$ & $\begin{array}{c}0.1730^{* * *} \\
(0.0535)\end{array}$ & $\begin{array}{c}0.1274^{* * *} \\
(0.0435)\end{array}$ \\
\hline NREGS Phase $3^{*}$ star & $\begin{array}{c}134425.6^{* * *} \\
(35612.88)\end{array}$ & $\begin{array}{l}-0.0078 \\
(0.0069)\end{array}$ & $\begin{array}{l}-0.0274 \\
(0.0380)\end{array}$ & $\begin{array}{l}0.0691^{*} \\
(0.0412)\end{array}$ & $\begin{array}{c}-0.2445^{* * *} \\
(0.0761)\end{array}$ & $\begin{array}{c}-0.1356^{* *} \\
(0.0545)\end{array}$ \\
\hline $\begin{array}{c}\text { NREGS Phase } 3 \\
\text { (Linear flexible) }\end{array}$ & $\begin{array}{c}-77555.1^{* * *} \\
(22451.19)\end{array}$ & $\begin{array}{l}-0.0010 \\
(0.0035)\end{array}$ & $\begin{array}{l}-0.0029 \\
(0.0295)\end{array}$ & $\begin{array}{l}-0.0263 \\
(0.0310)\end{array}$ & $\begin{array}{c}0.1621^{* * *} \\
(0.0604)\end{array}$ & $\begin{array}{c}0.1757^{* * * *} \\
(0.0499)\end{array}$ \\
\hline NREGS Phase $3^{*}$ star & $\begin{array}{c}175921.2^{* * *} \\
(48846.17)\end{array}$ & $\begin{array}{l}-0.0053 \\
(0.0084)\end{array}$ & $\begin{array}{l}-0.0127 \\
(0.0572)\end{array}$ & $\begin{array}{c}0.0242 \\
(0.0635)\end{array}$ & $\begin{array}{r}-0.1964^{*} \\
(0.1154)\end{array}$ & $\begin{array}{c}-0.1396^{*} \\
(0.0808)\end{array}$ \\
\hline $\begin{array}{c}\text { NREGS Phase } 3 \\
\text { (Quadratic) }\end{array}$ & $\begin{array}{c}-61627.13^{* * *} \\
(22504.39)\end{array}$ & $\begin{array}{c}0.0010 \\
(0.0037)\end{array}$ & $\begin{array}{c}0.0010 \\
(0.0289)\end{array}$ & $\begin{array}{l}-0.0397 \\
(0.0307)\end{array}$ & $\begin{array}{c}0.1679 * * * \\
(0.0594)\end{array}$ & $\begin{array}{c}0.1533^{* * *} \\
(0.0468)\end{array}$ \\
\hline NREGS Phase $3^{*}$ star & $\begin{array}{c}139842.1^{* * *} \\
(37054.97)\end{array}$ & $\begin{array}{l}-0.0092 \\
(0.0071)\end{array}$ & $\begin{array}{l}-0.0139 \\
(0.0391)\end{array}$ & $\begin{array}{c}0.0461 \\
(0.0425)\end{array}$ & $\begin{array}{c}-0.2480^{* * *} \\
(0.0783)\end{array}$ & $\begin{array}{c}-0.1168^{* *} \\
(0.0564)\end{array}$ \\
\hline
\end{tabular}

$\begin{array}{lllllll}\mathrm{N} & 406 & 406 & 406 & 406 & 406 & 406\end{array}$

Note: ${ }^{* *} \mathrm{p}<0.01,{ }^{* *} \mathrm{p}<0.05,{ }^{*} \mathrm{p}<0.1$ Standard errors clustered at the district level in parentheses. An observation is an election constituency in the 2009 general election. Parametric regressions with different levels of flexibility are reported. 